\title{
1,2-Dihydroisoquinolines as Templates for Cascade Reactions to Access Isoquinoline Alkaloid Frameworks
}

\author{
Shun Su and John A. Porco, Jr.* \\ Department of Chemistry and Center for Chemical Methodology and Library Development (CMLD- \\ BU), Boston University, 590 Commonwealth Avenue, Boston, Massachusetts 02215 \\ Supporting Information \\ ${ }^{1} \mathrm{H},{ }^{13} \mathrm{C}$, and other NMR Spectra
}




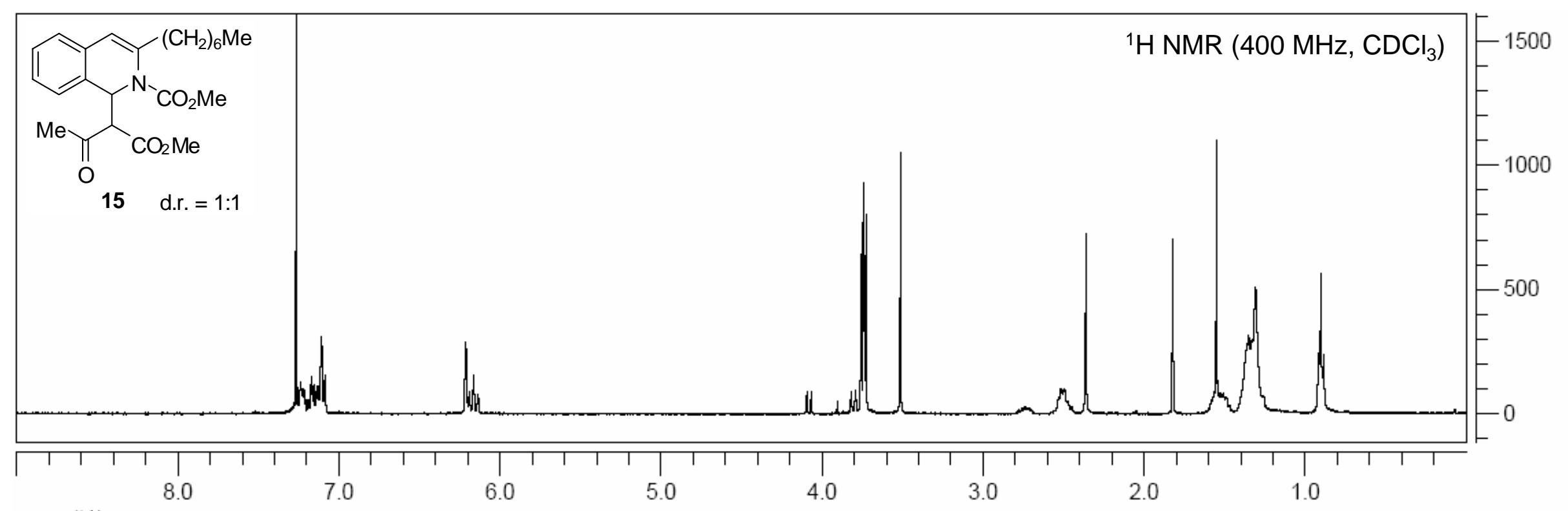

ppm (t1)

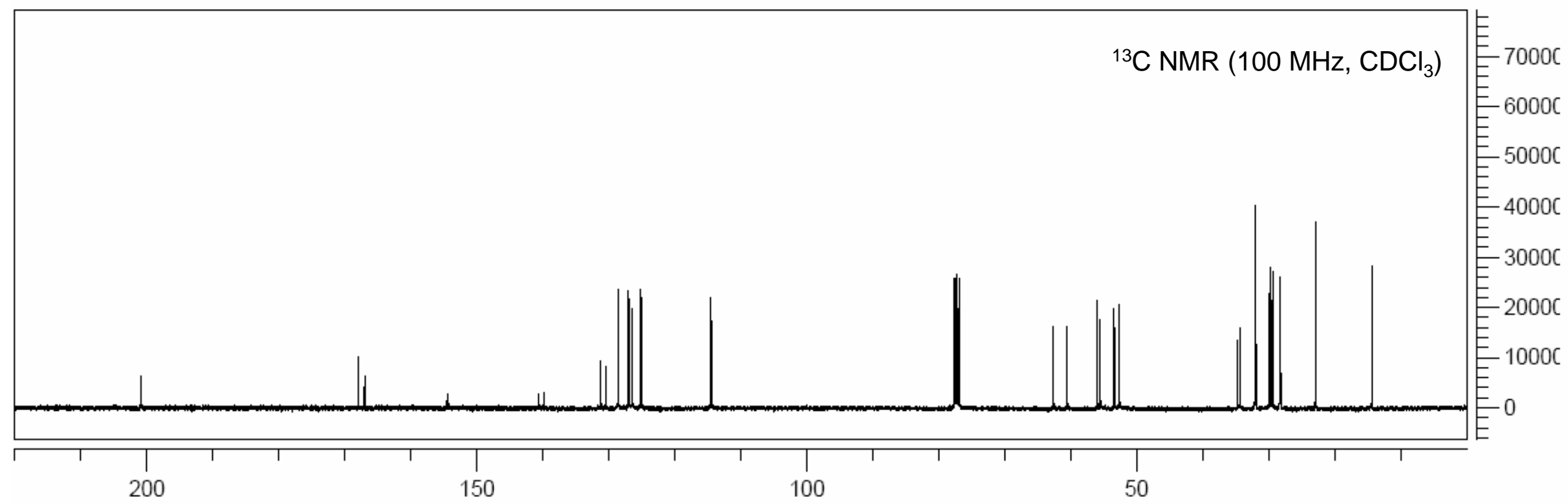

ppm (t1) 


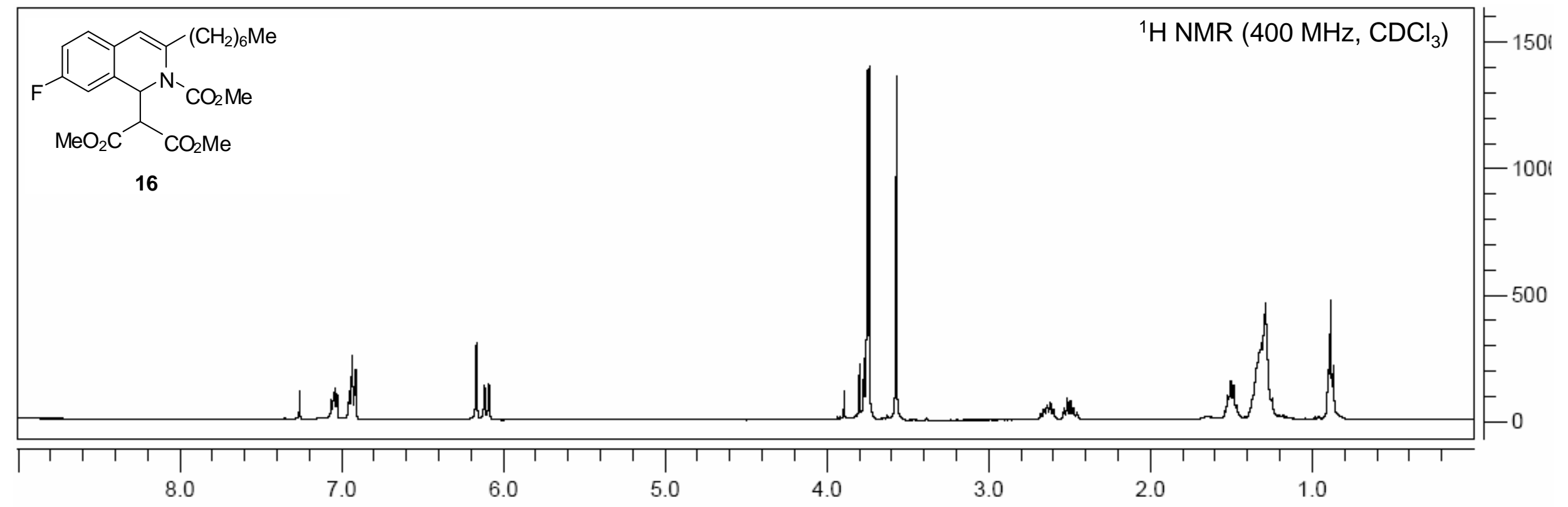

ppm (t1)

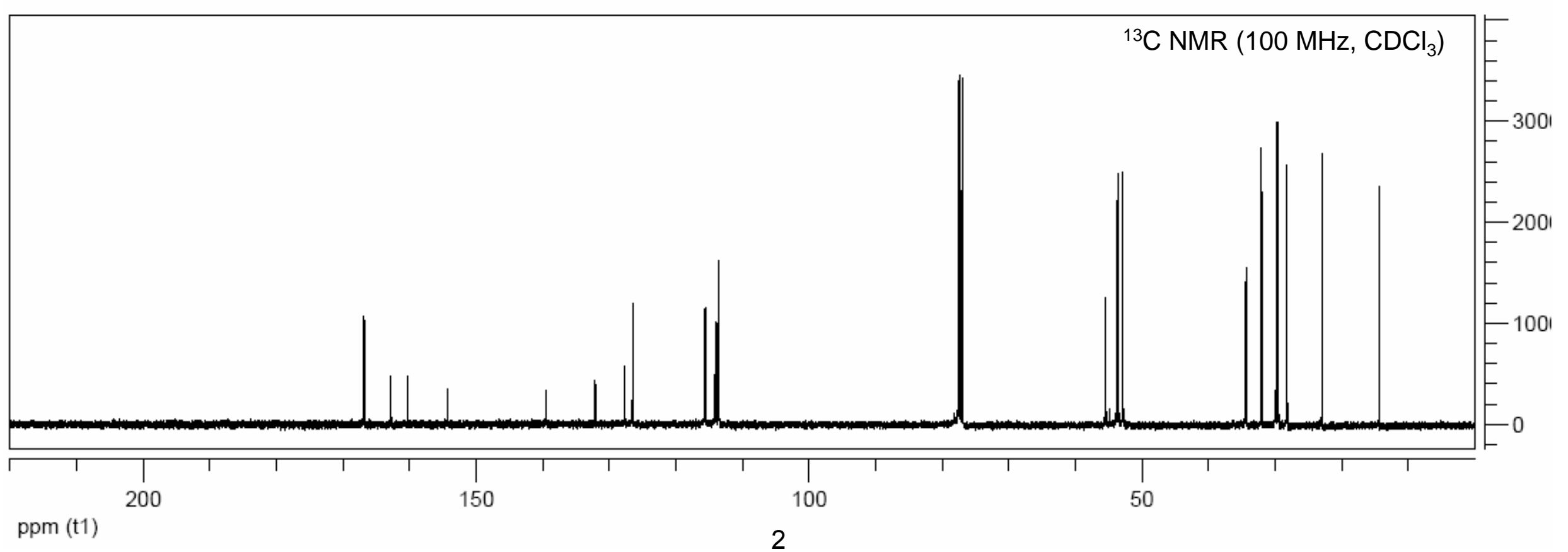




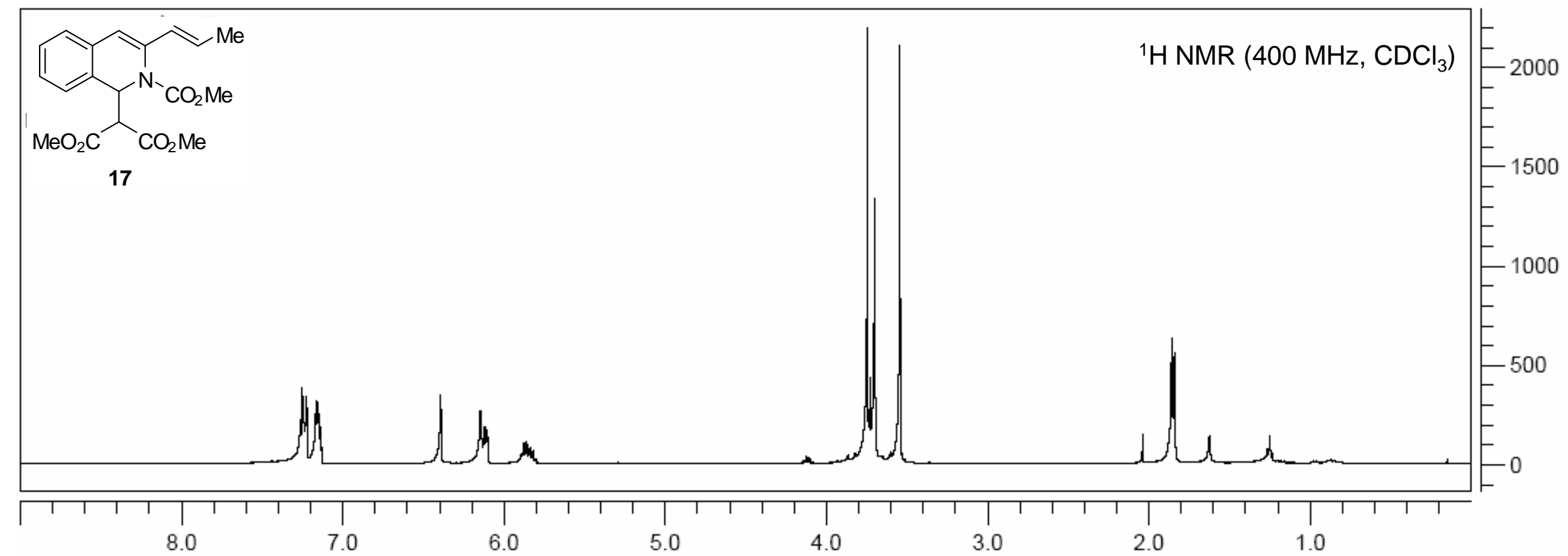

ppm (t1)

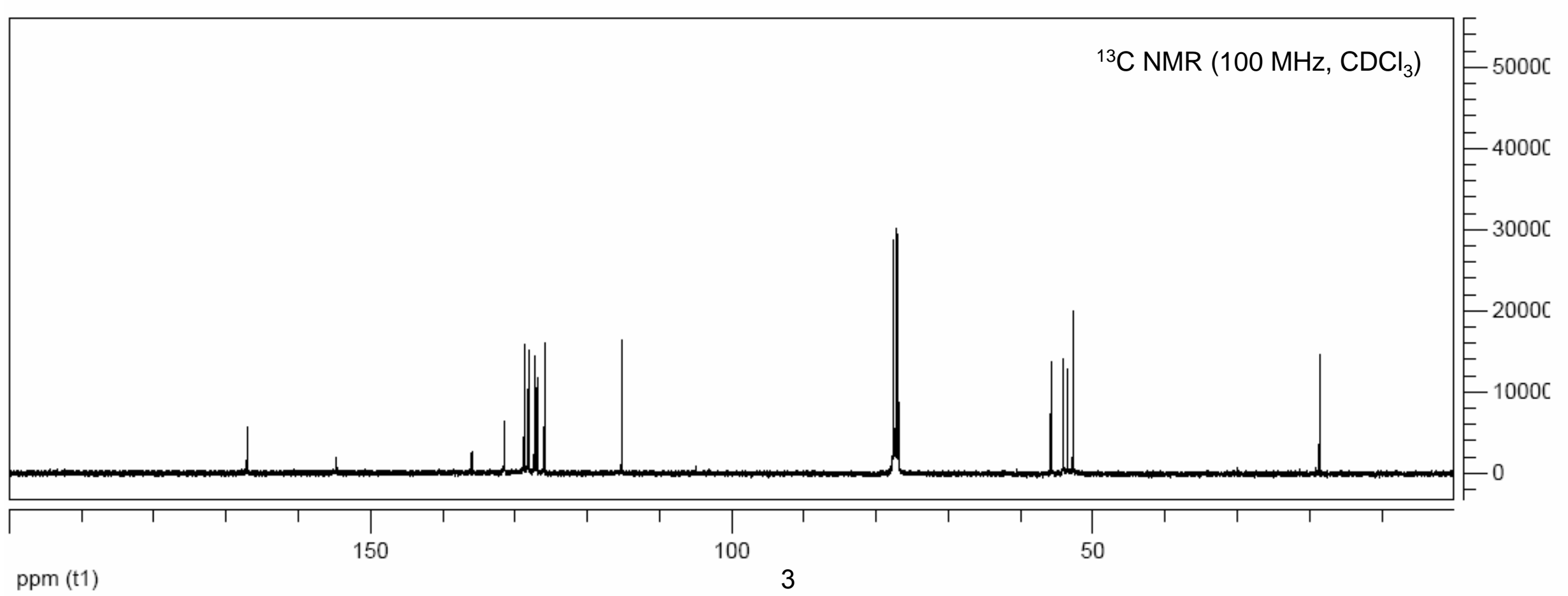




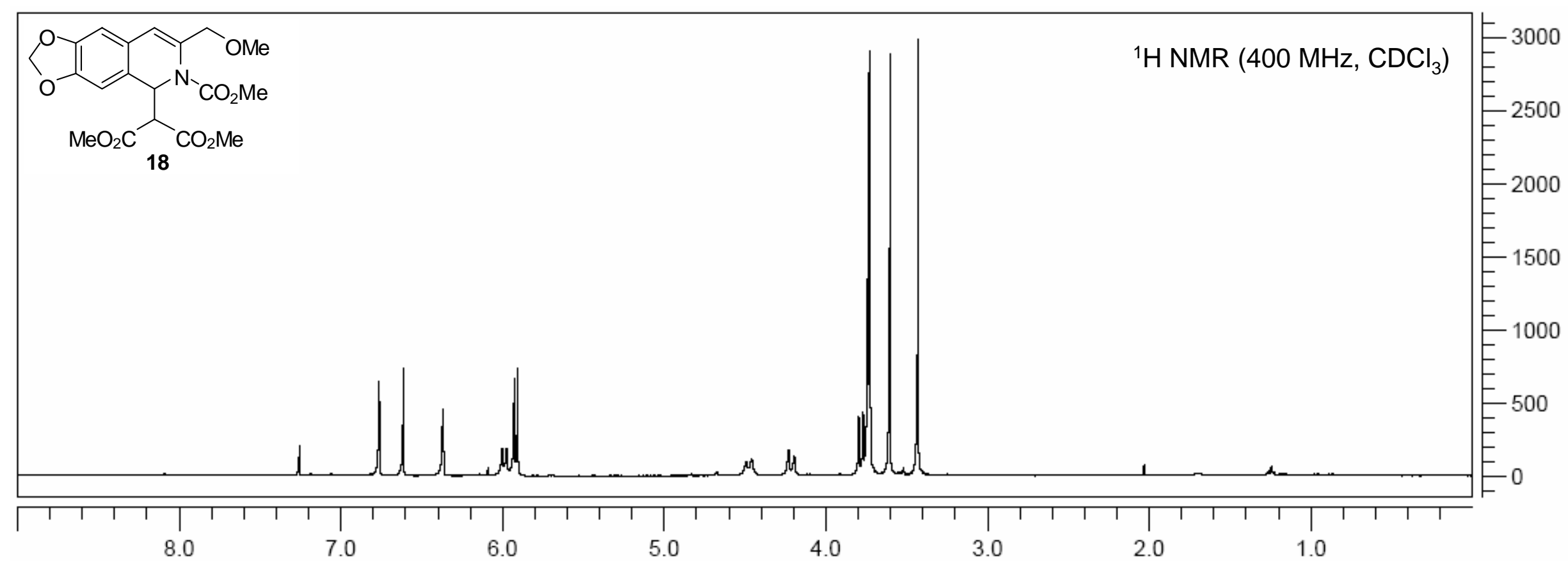

ppm (t1)

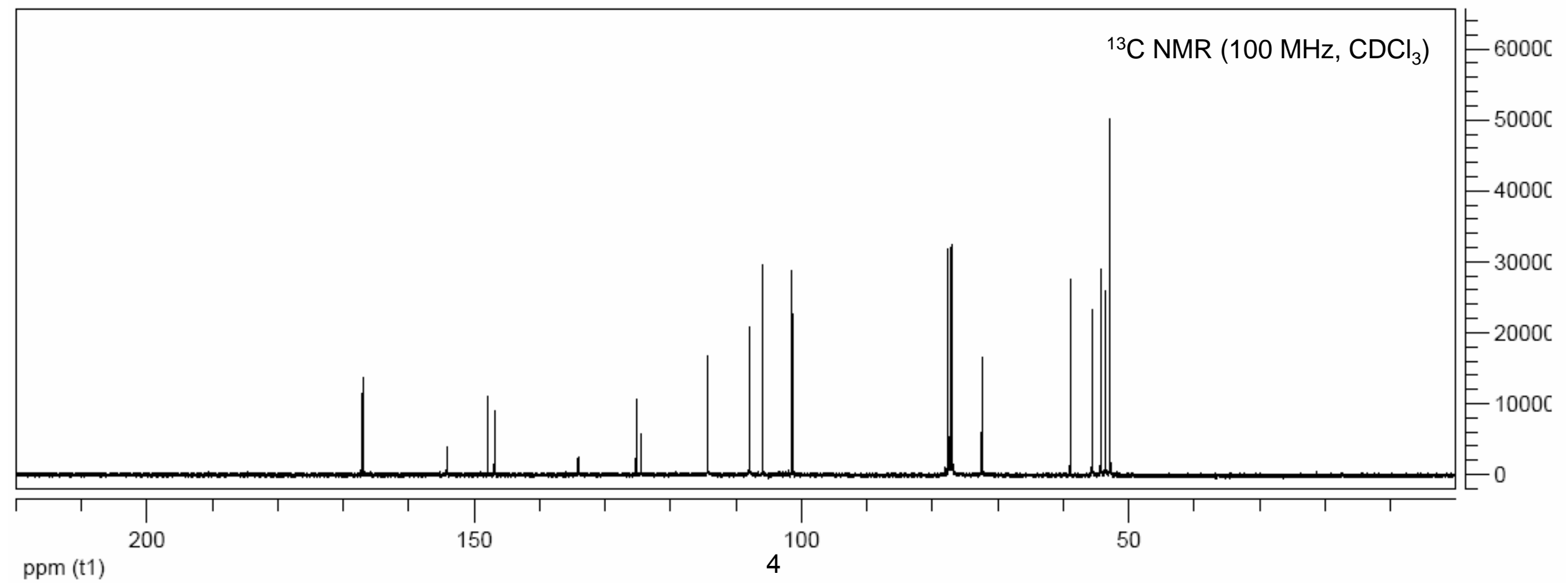




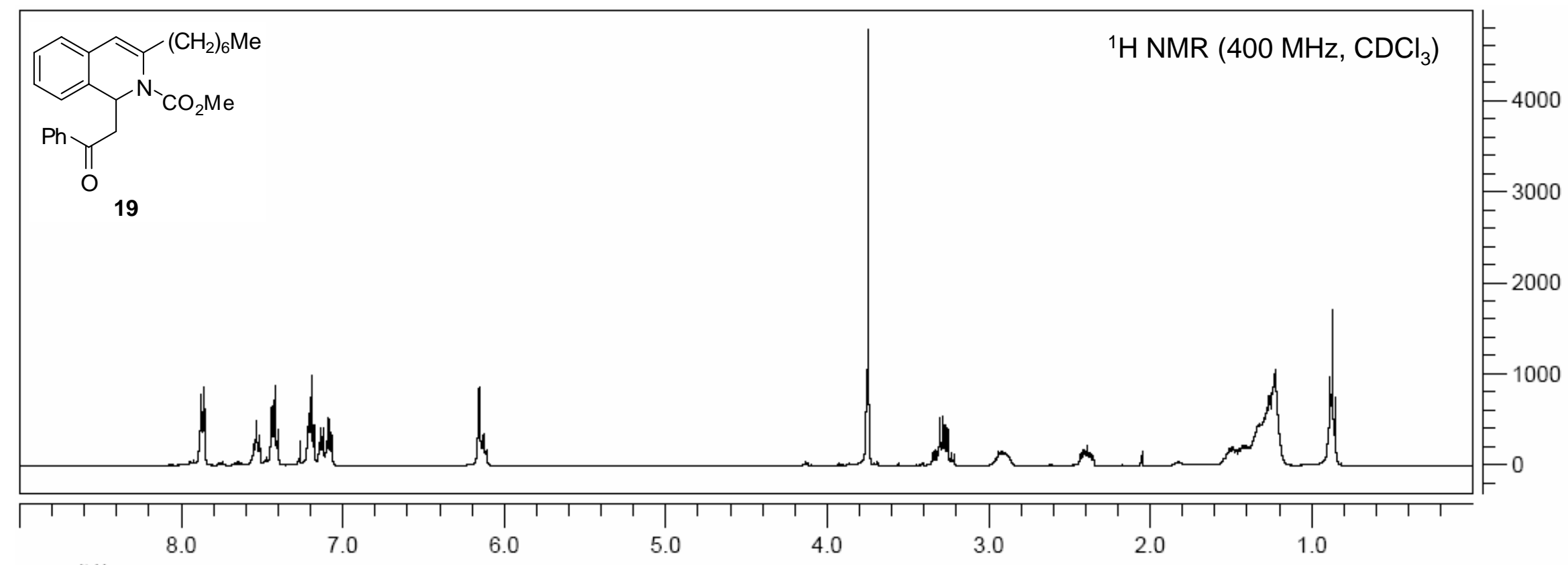

ppm (t1)

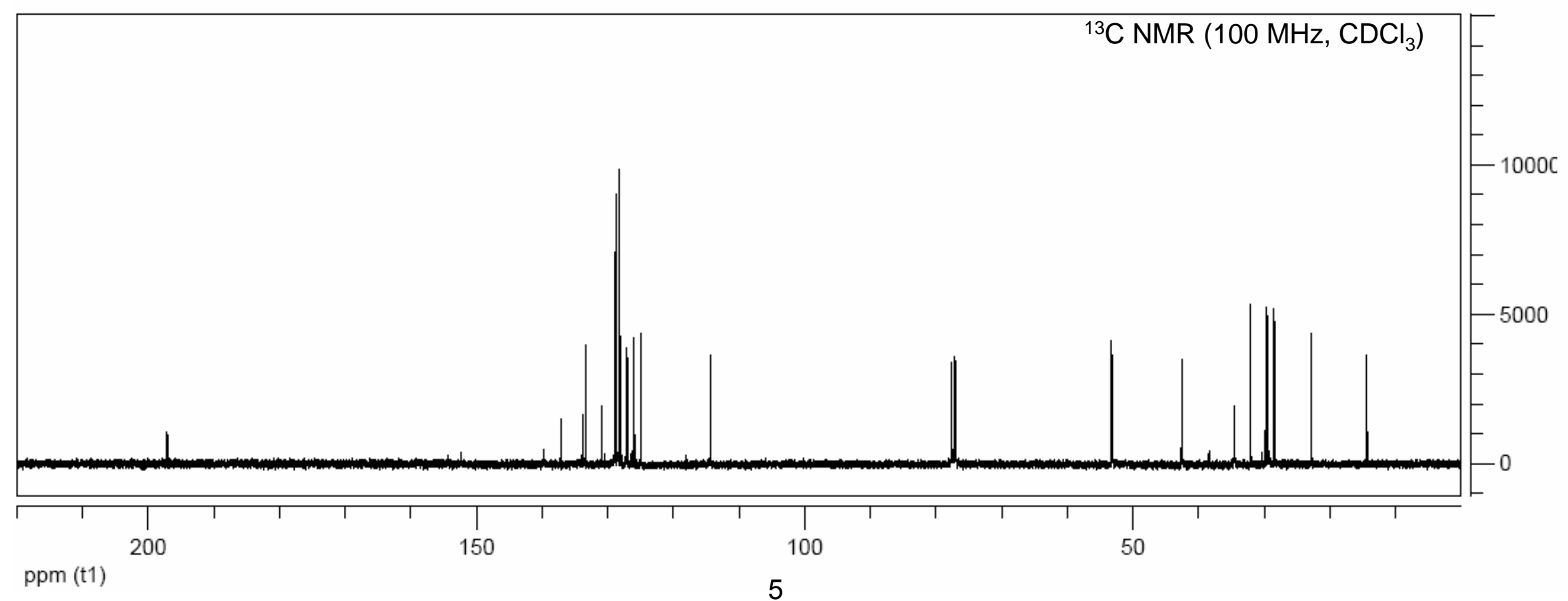



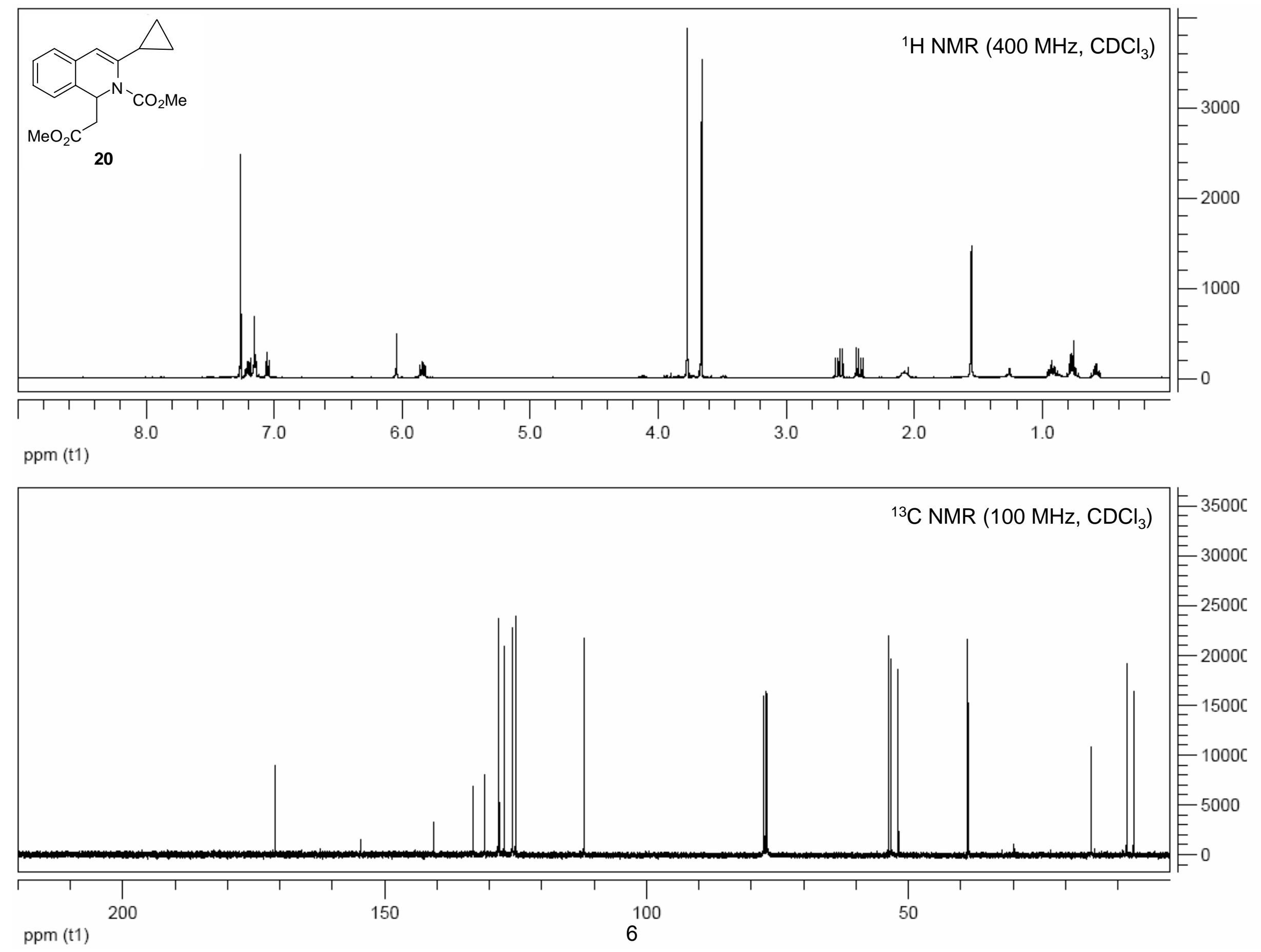

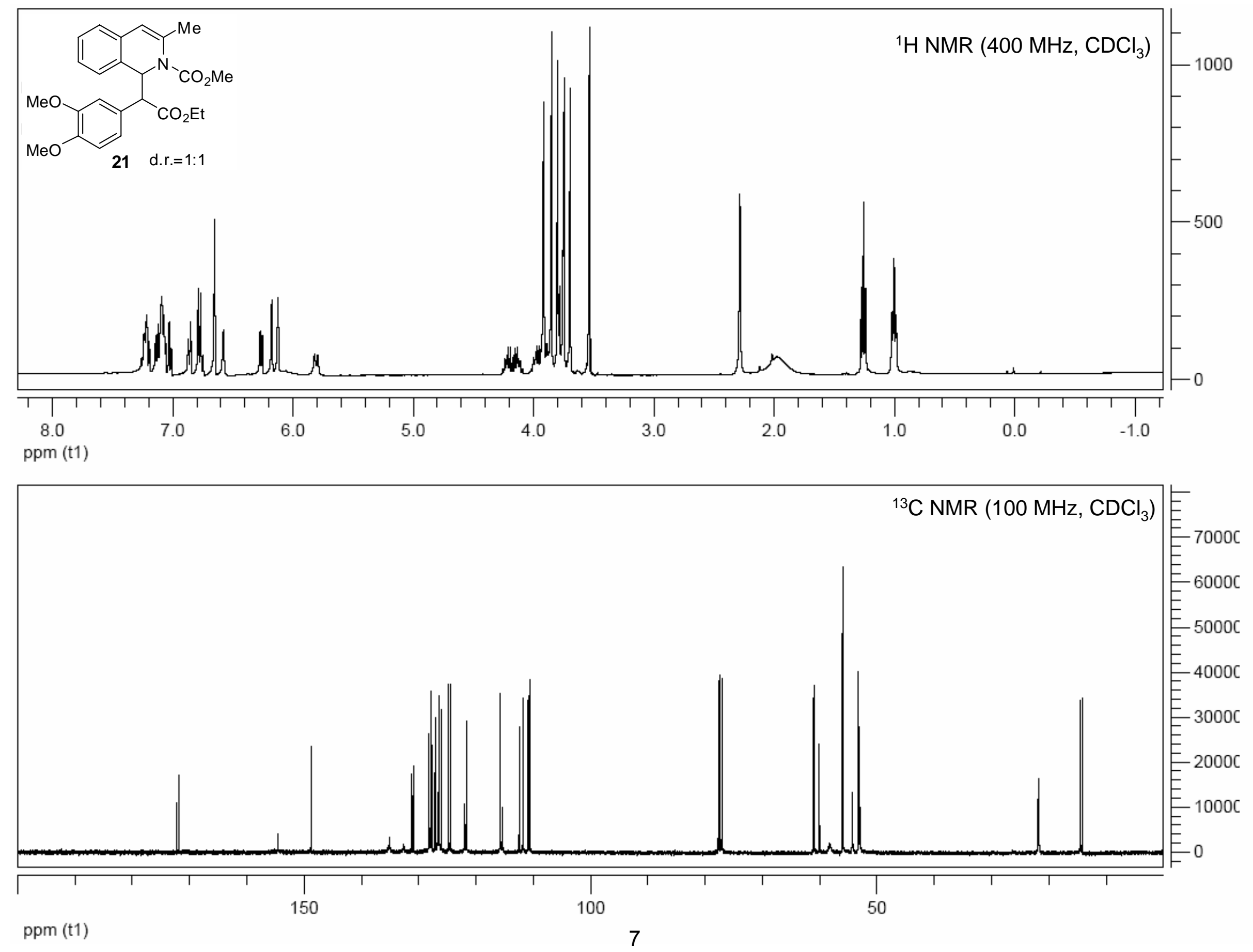


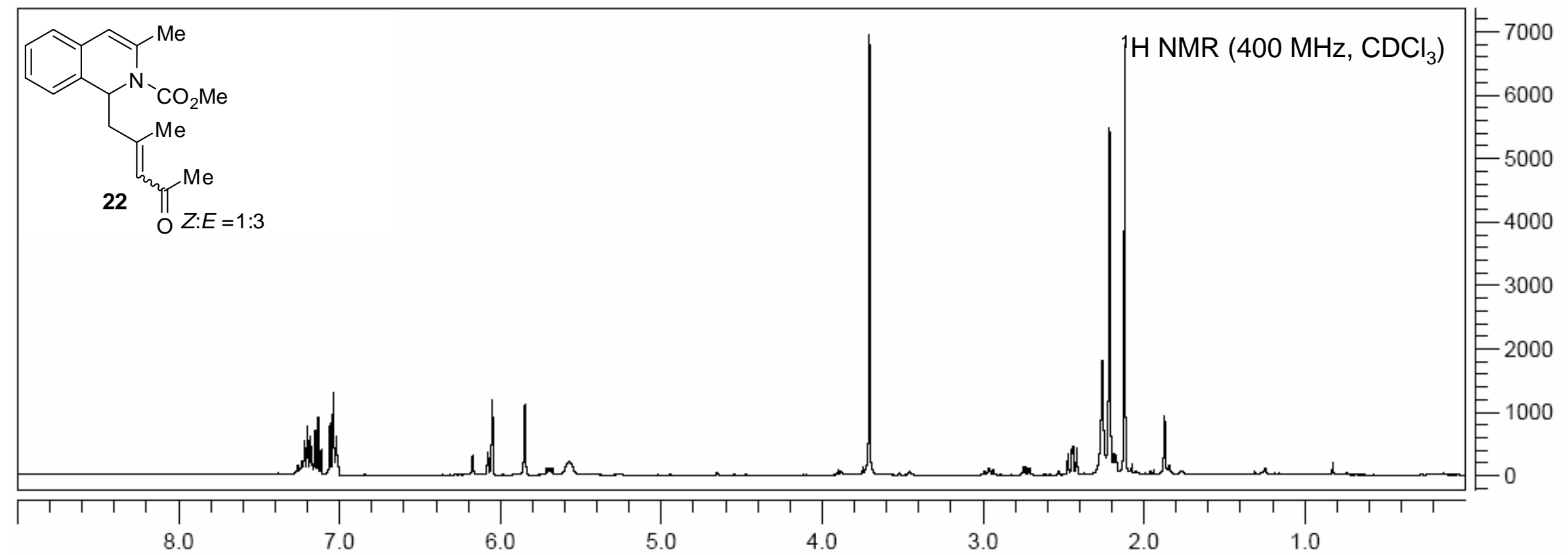

ppm (t1)

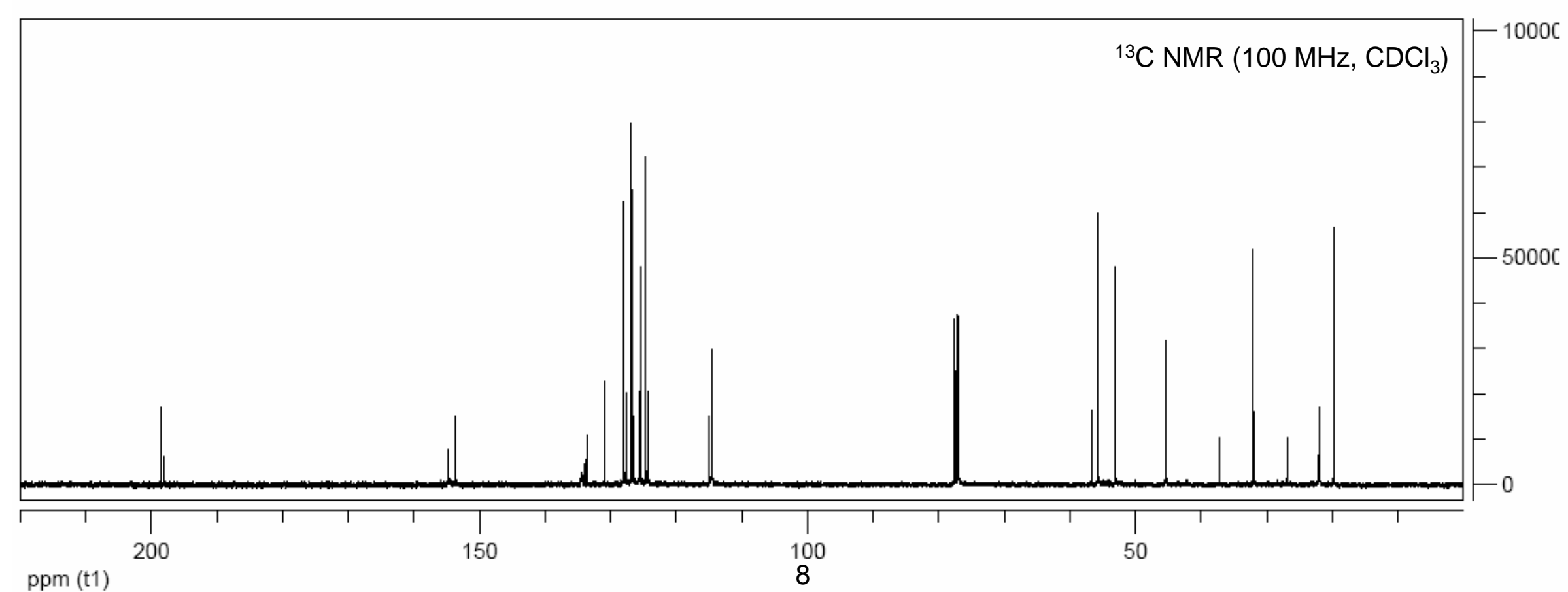




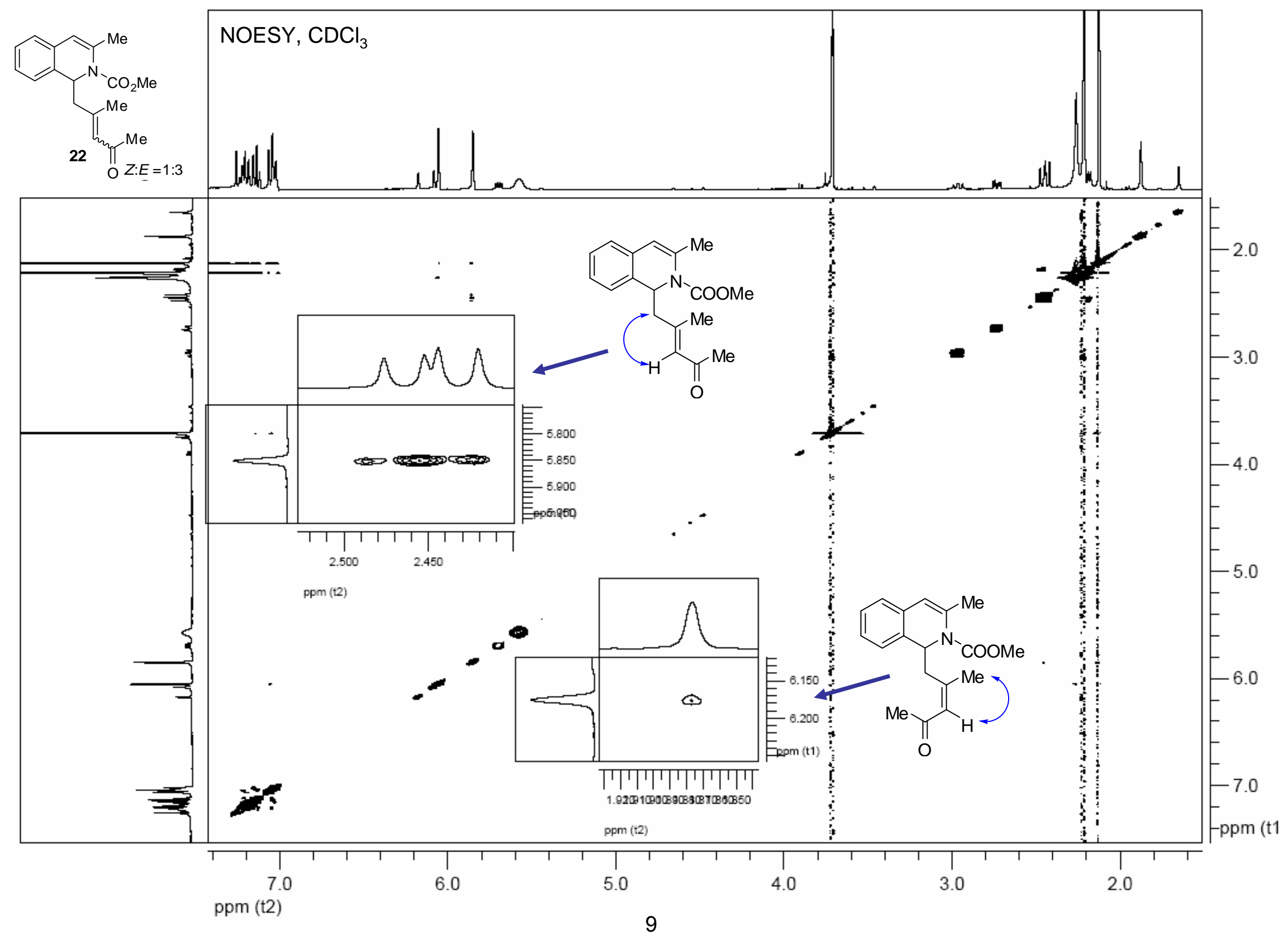



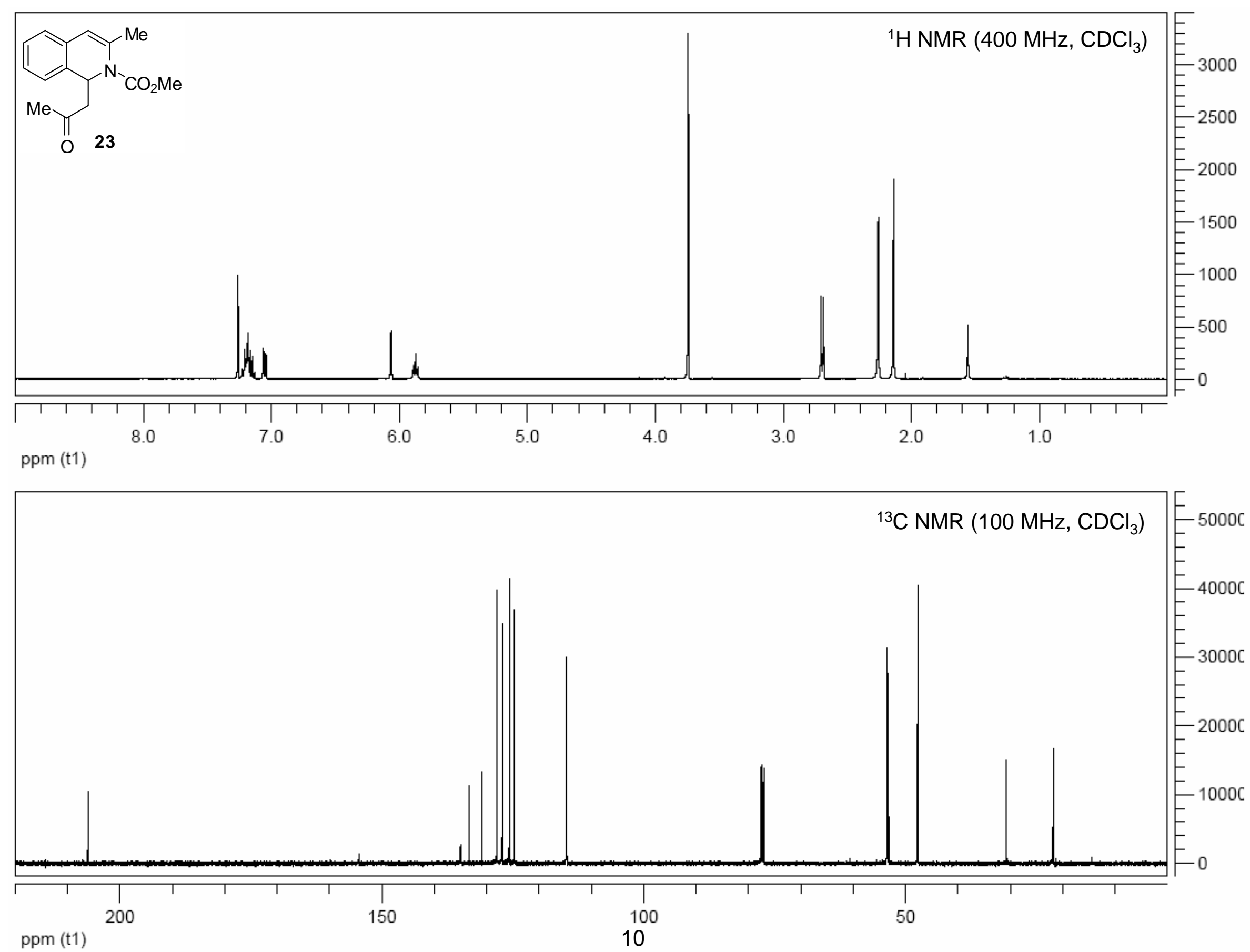


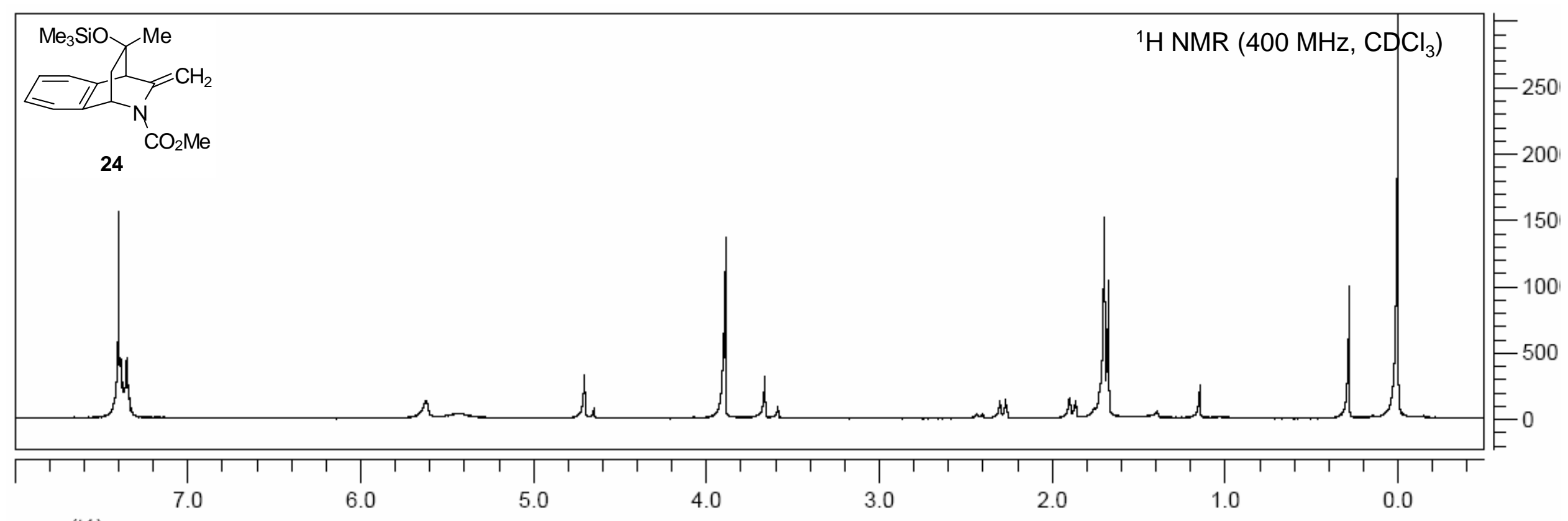

ppm (t1)

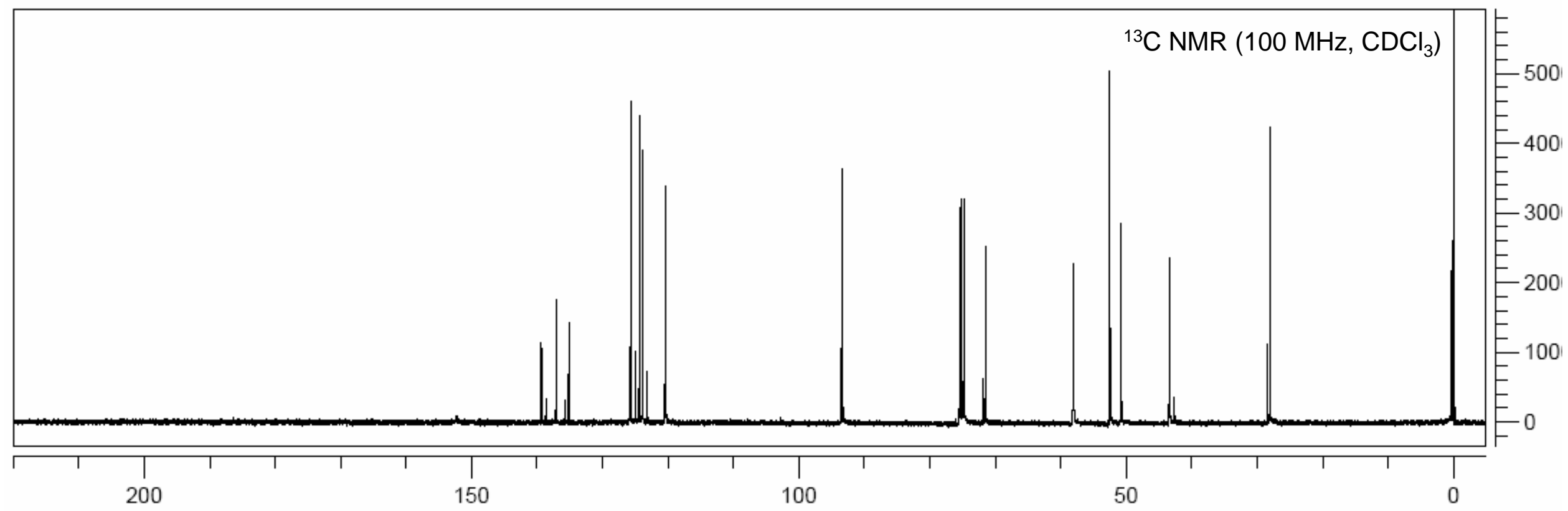




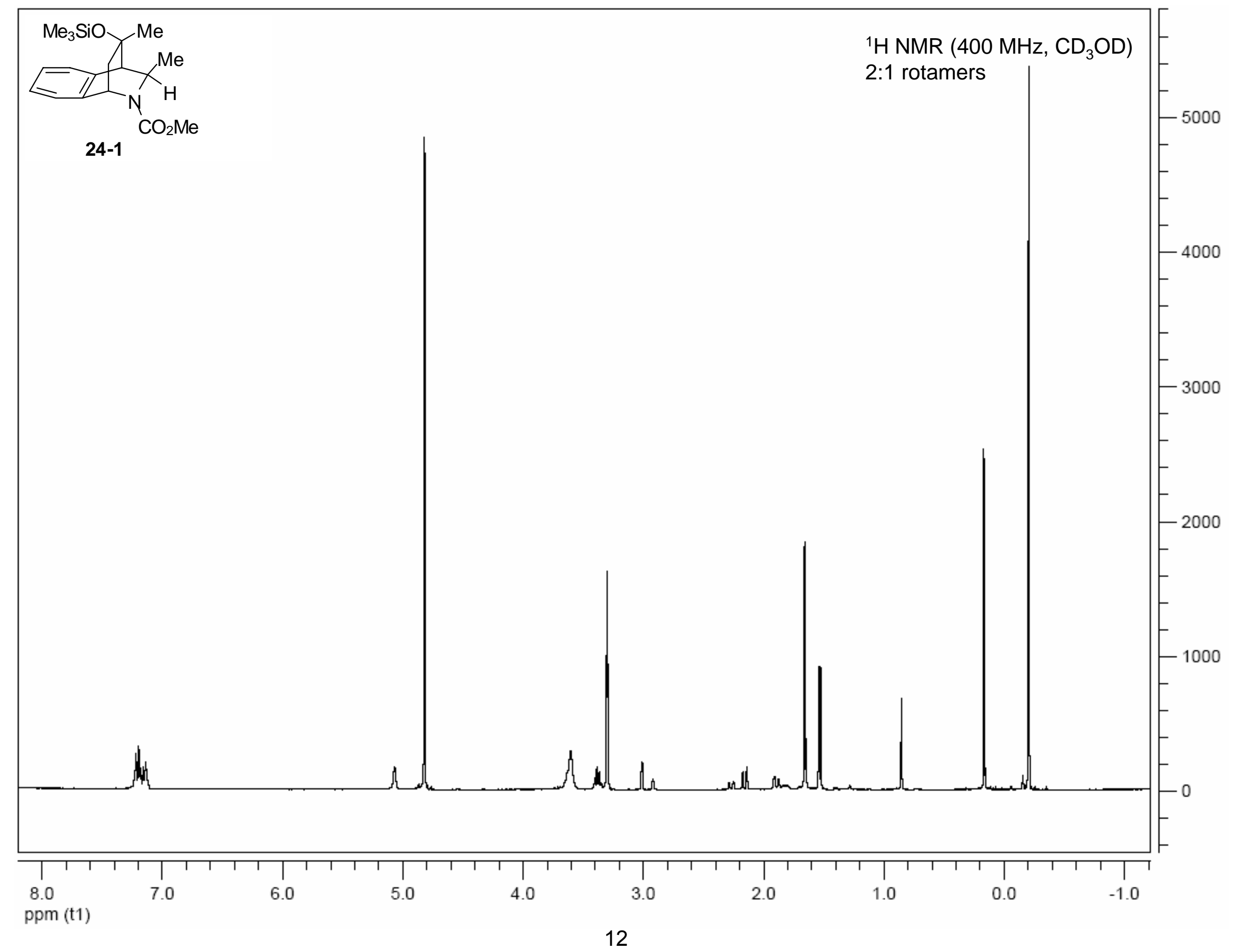




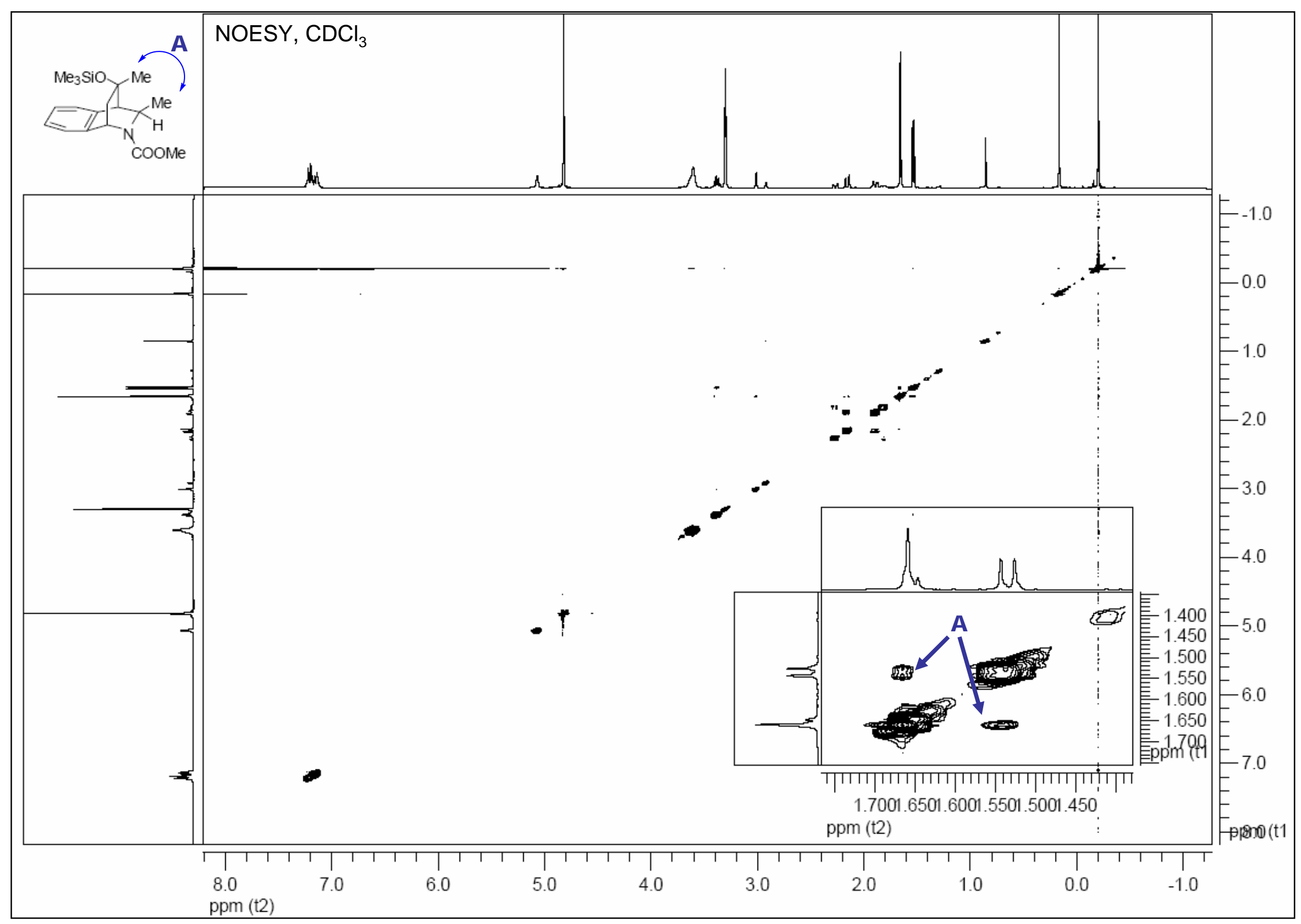




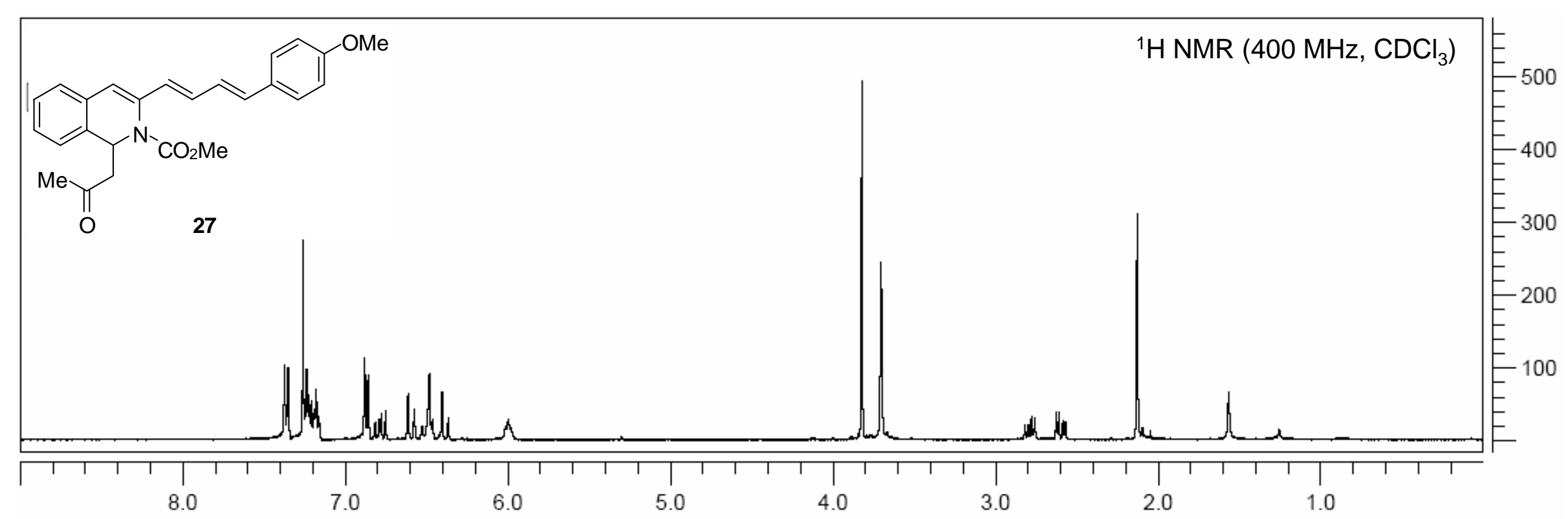

ppm (t1)

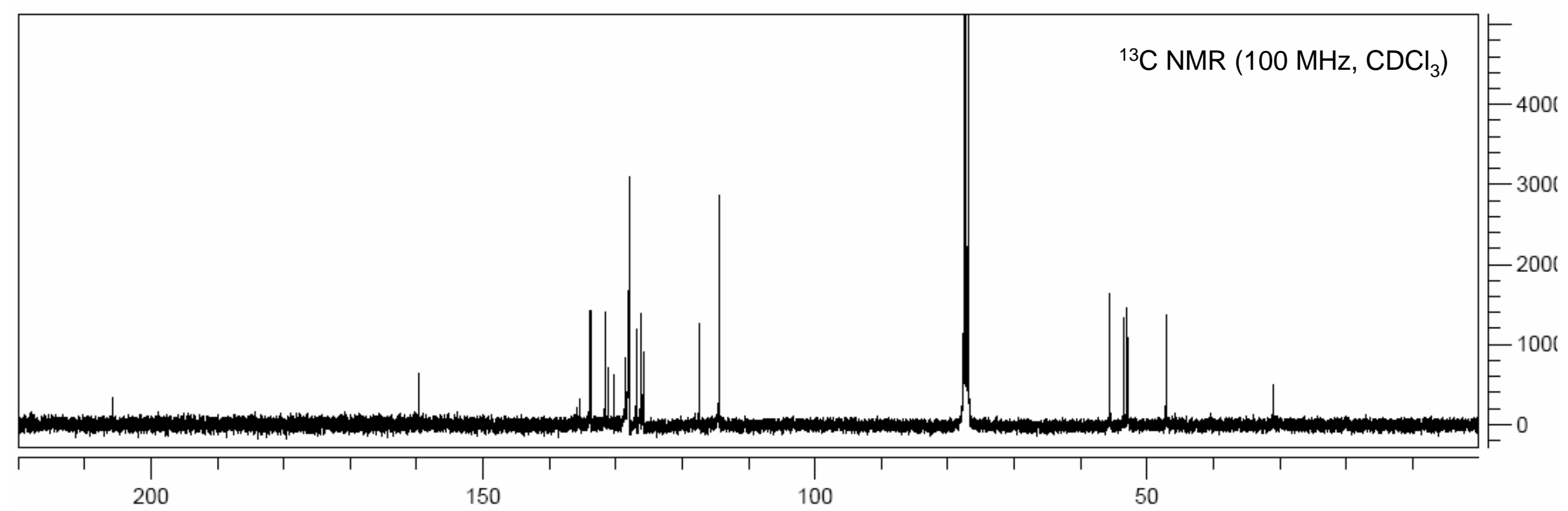

ppm (t1) 


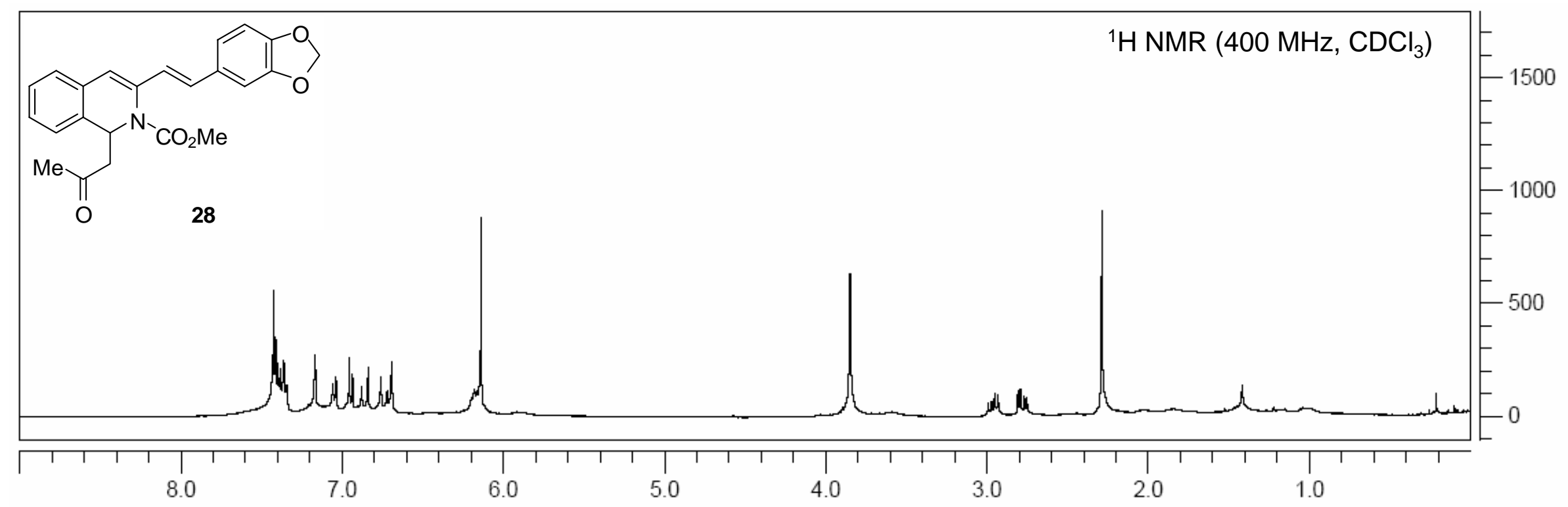

ppm (t1)

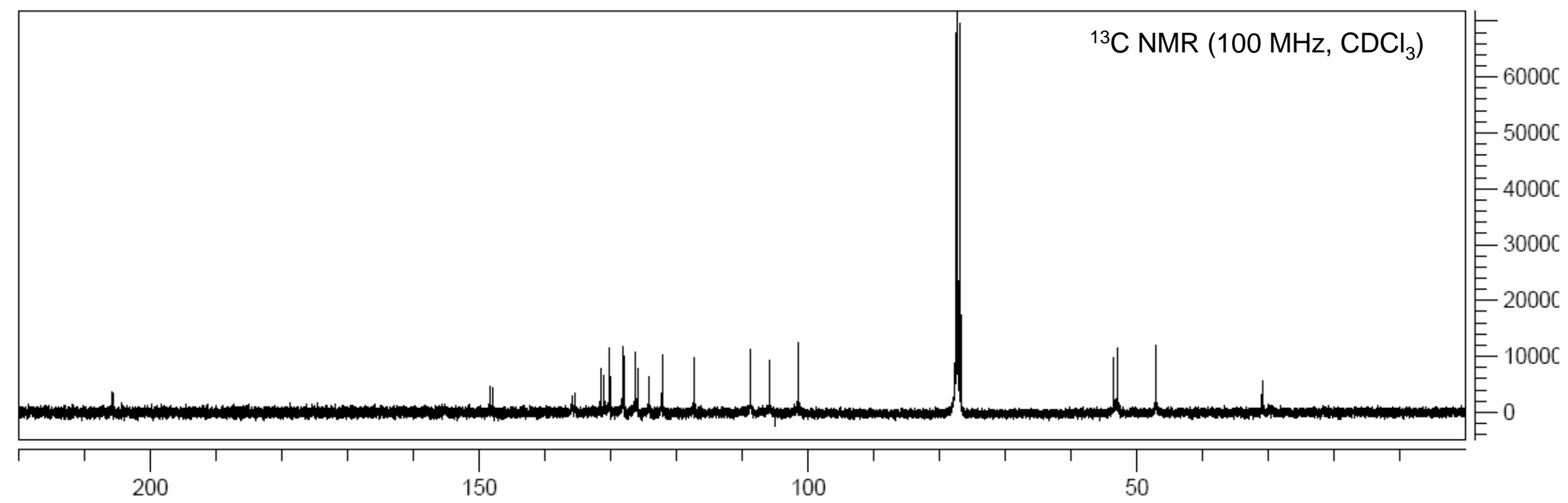

ppm (f1) 


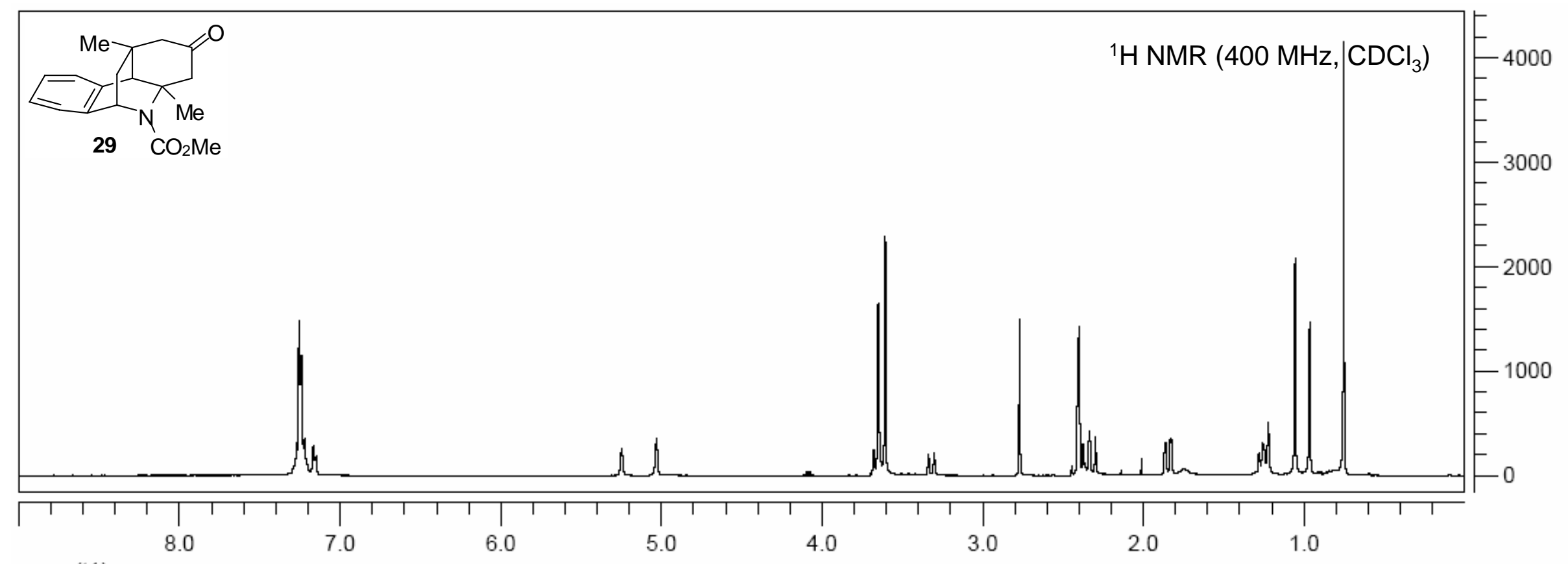

ppm (t1)

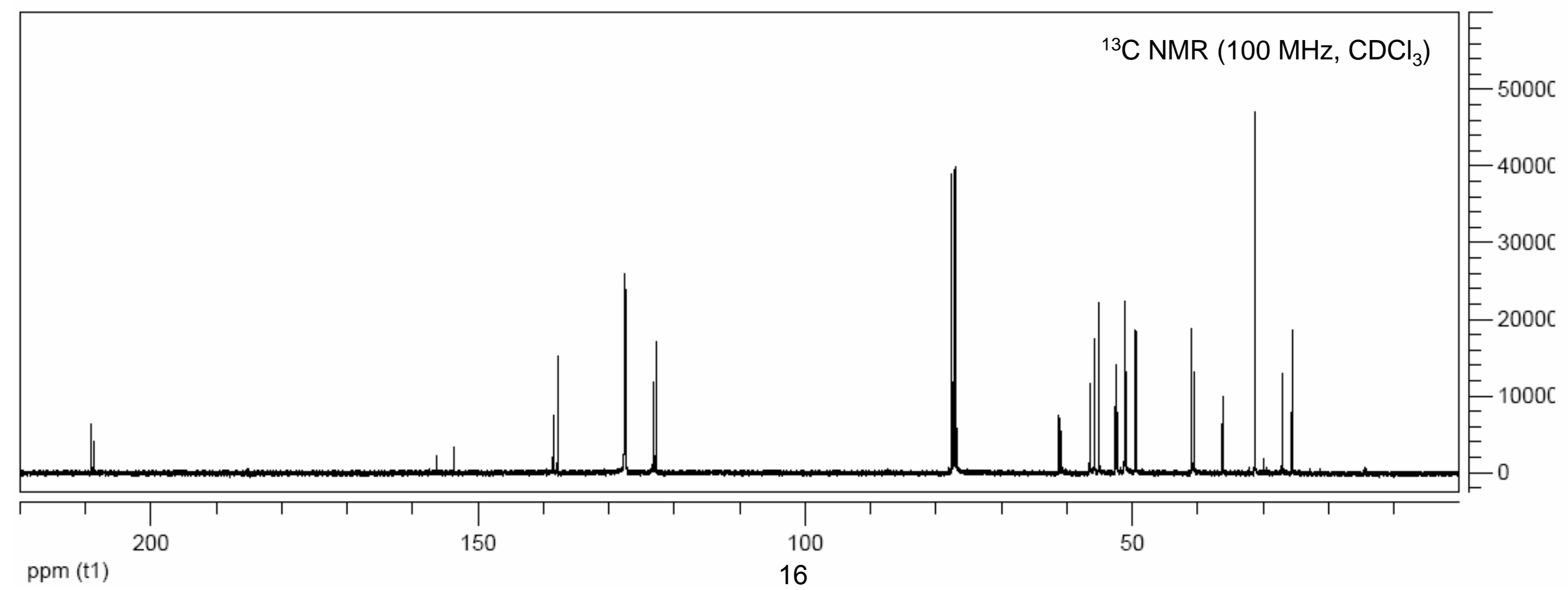




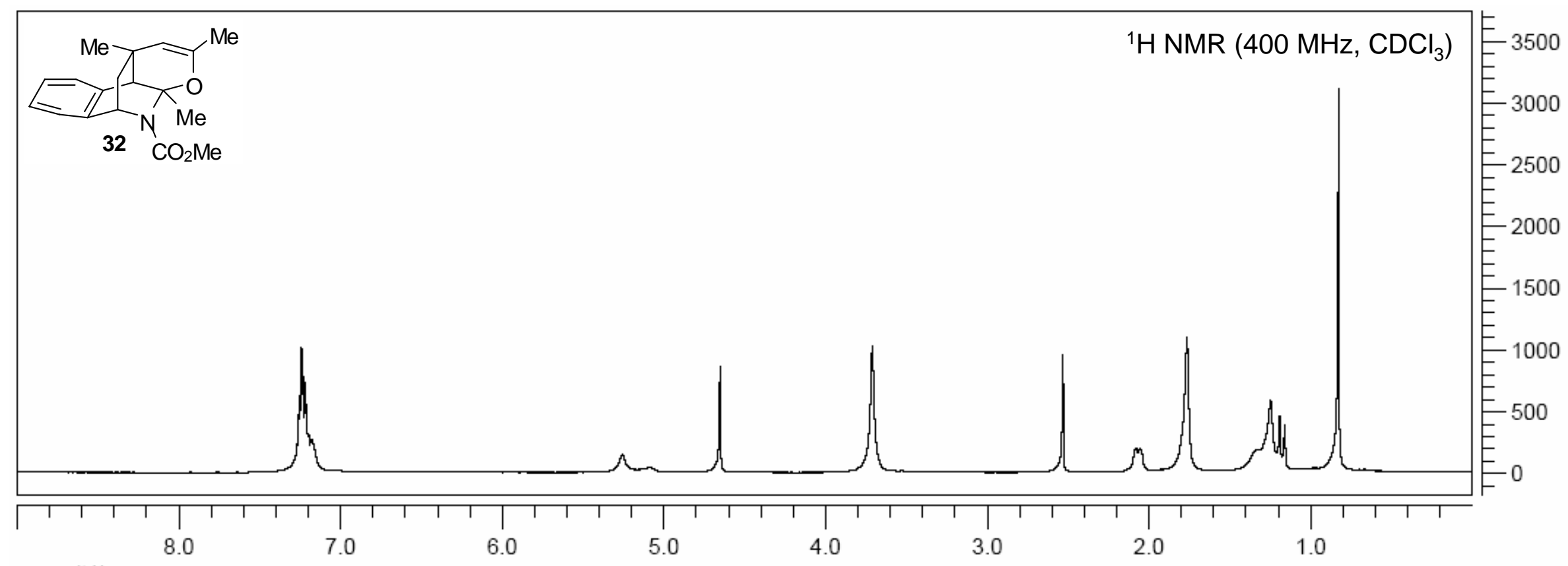

ppm (t1)

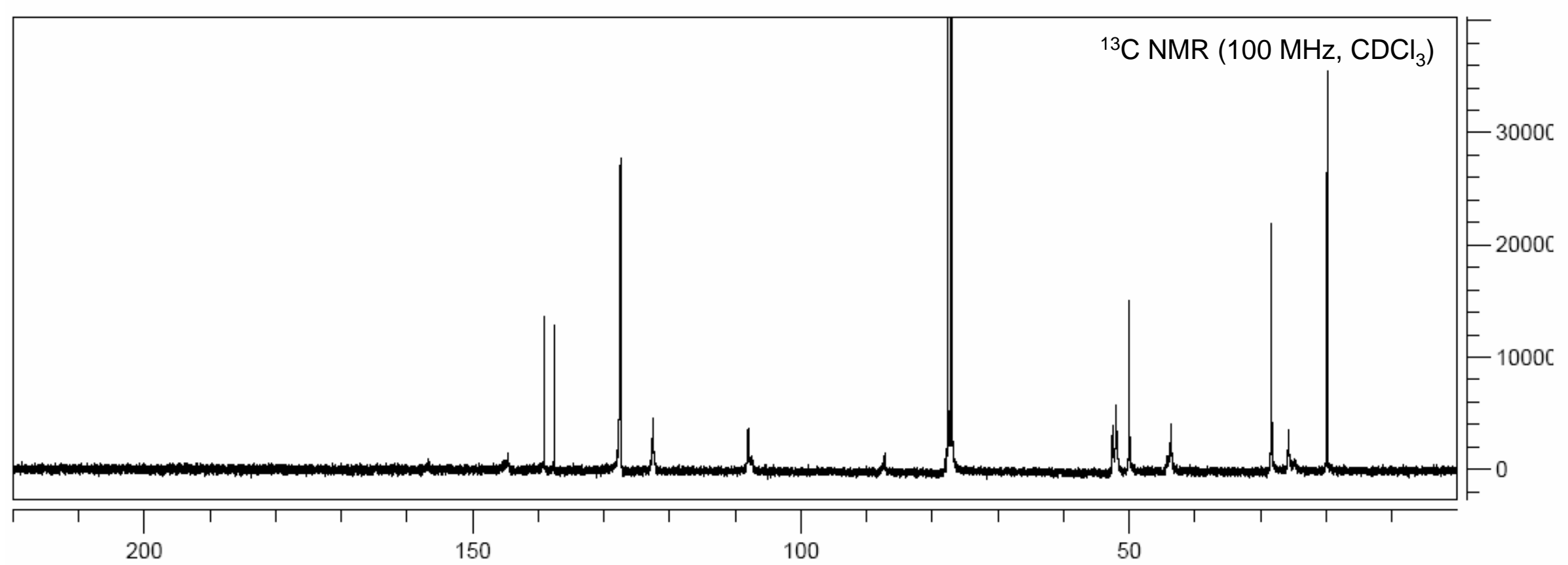

ppm (t1) 


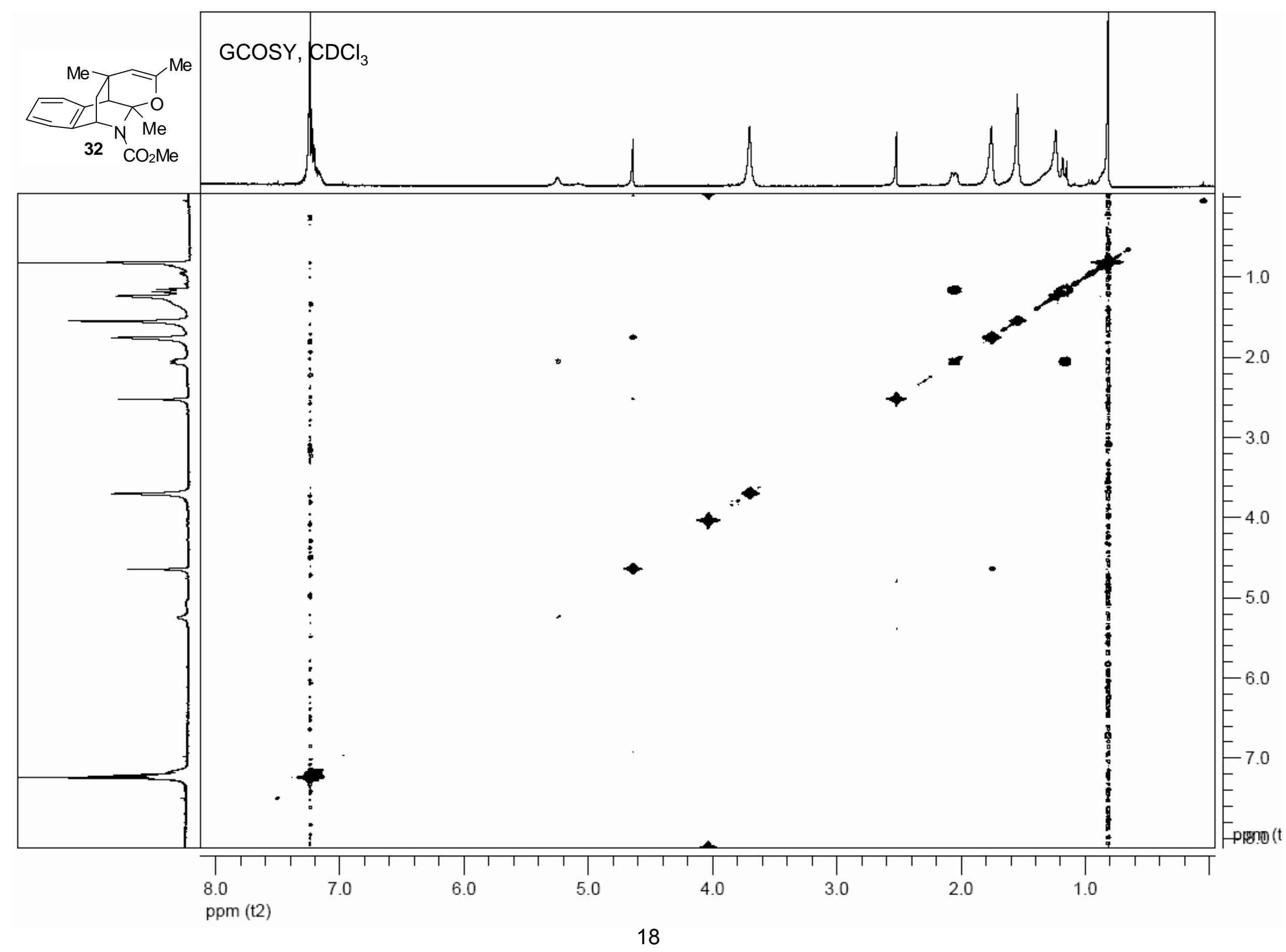




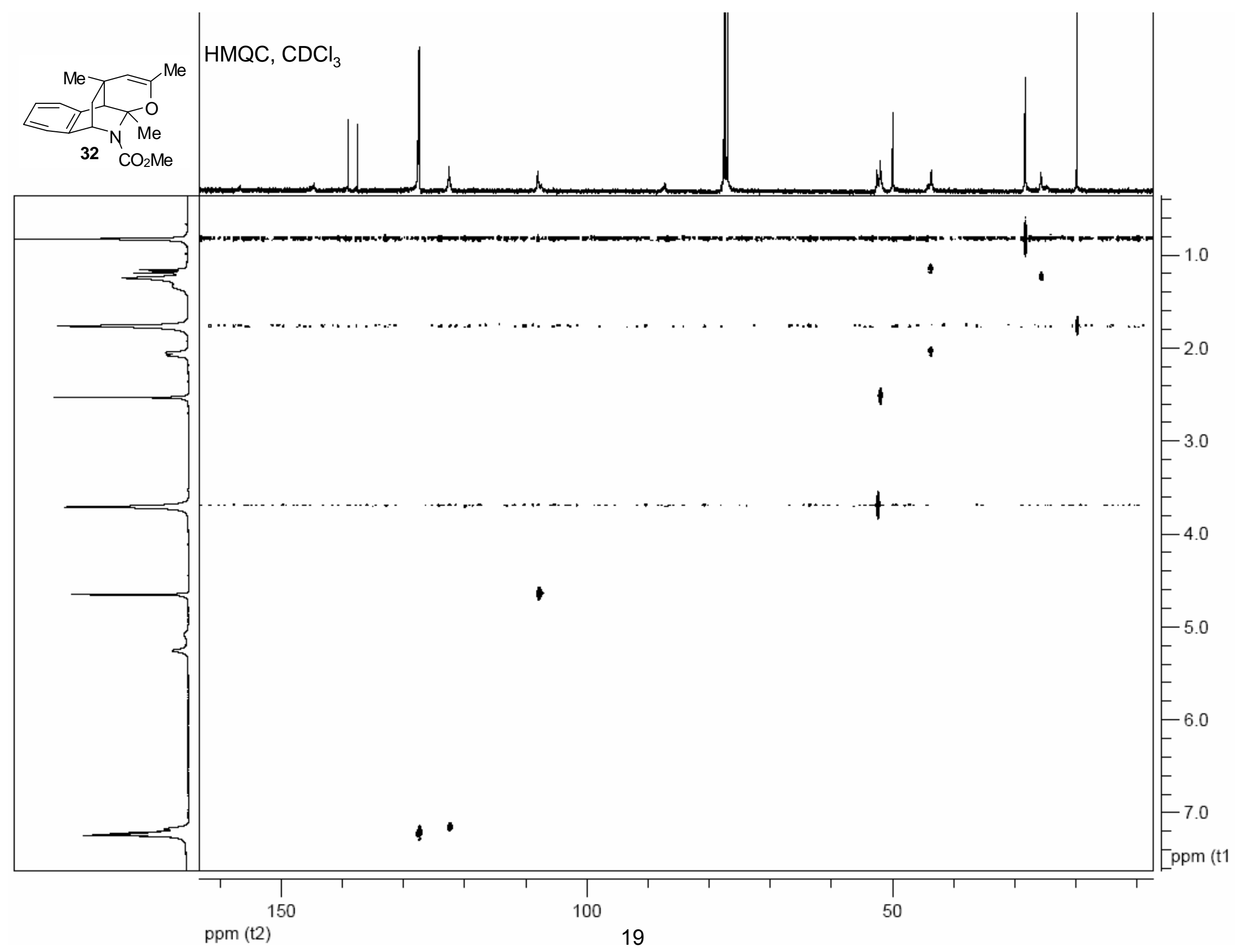




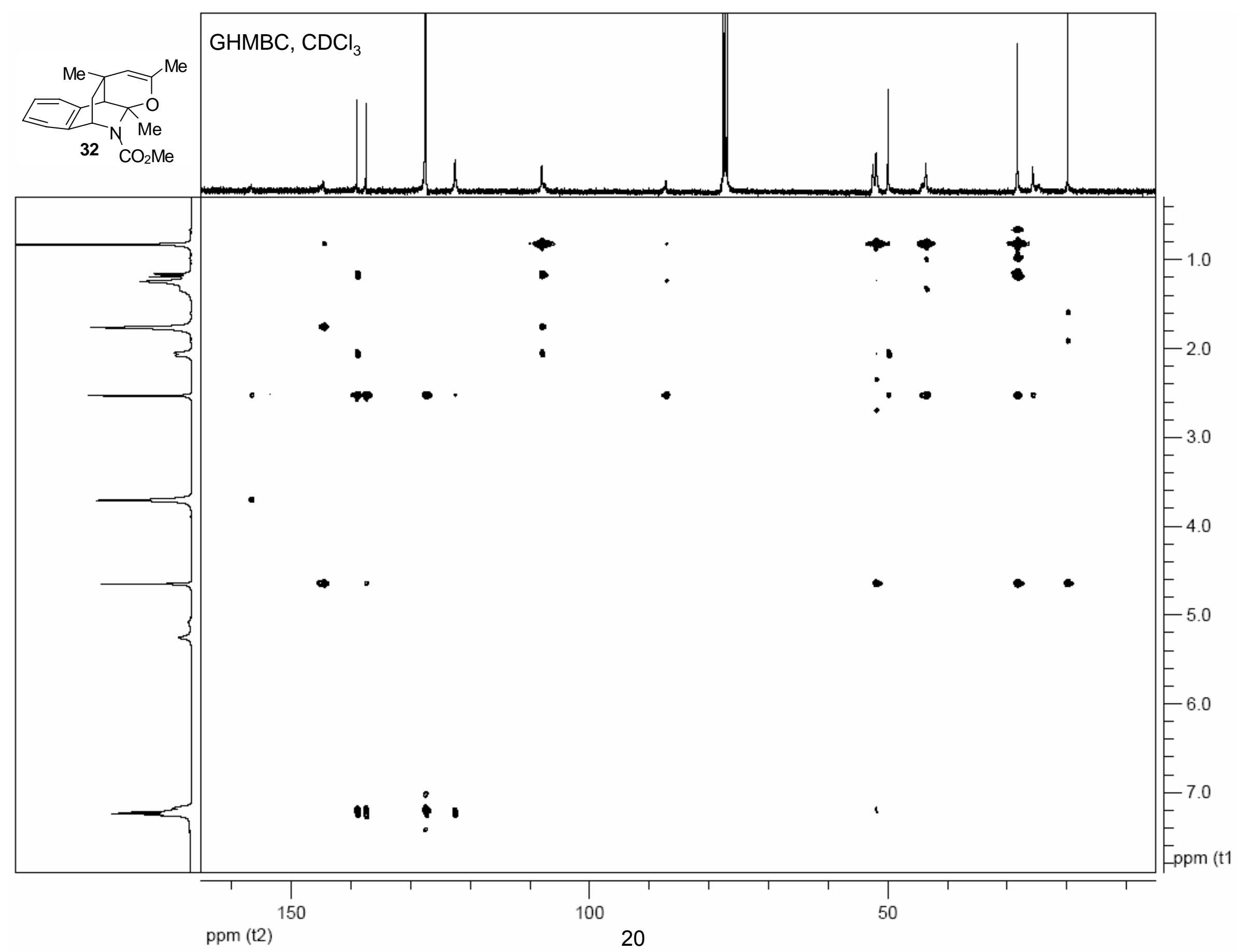




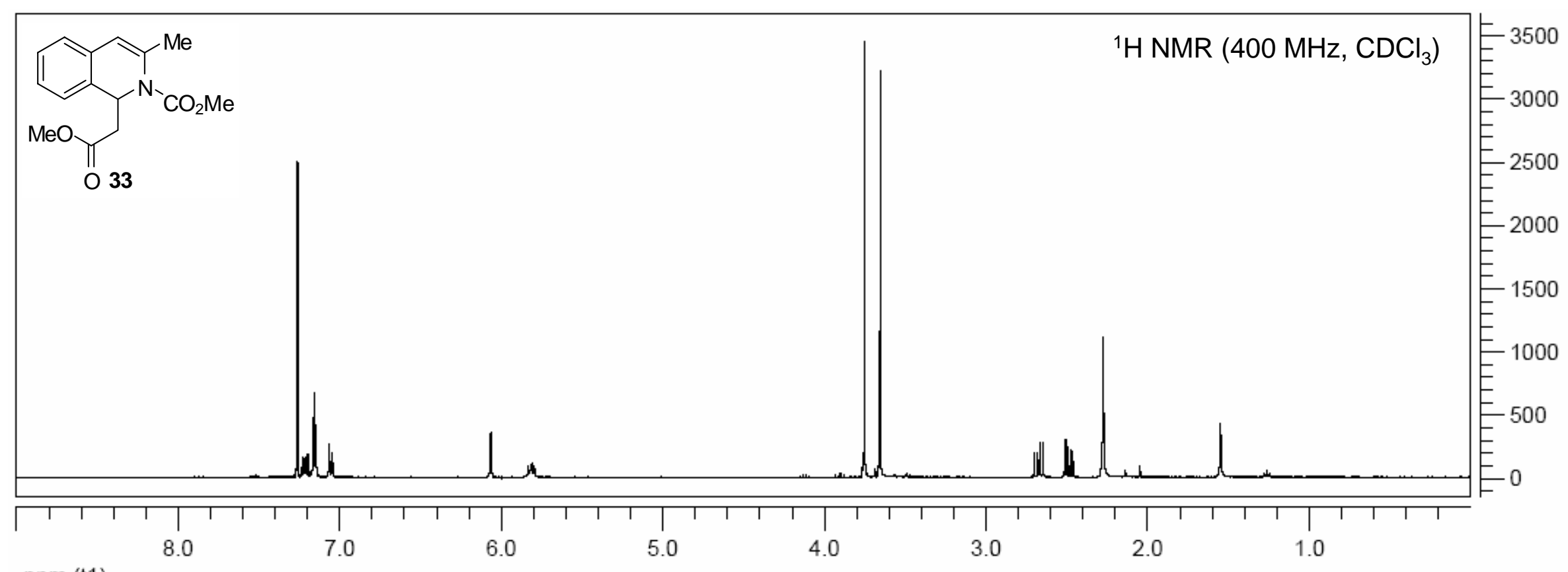

ppm (t1)

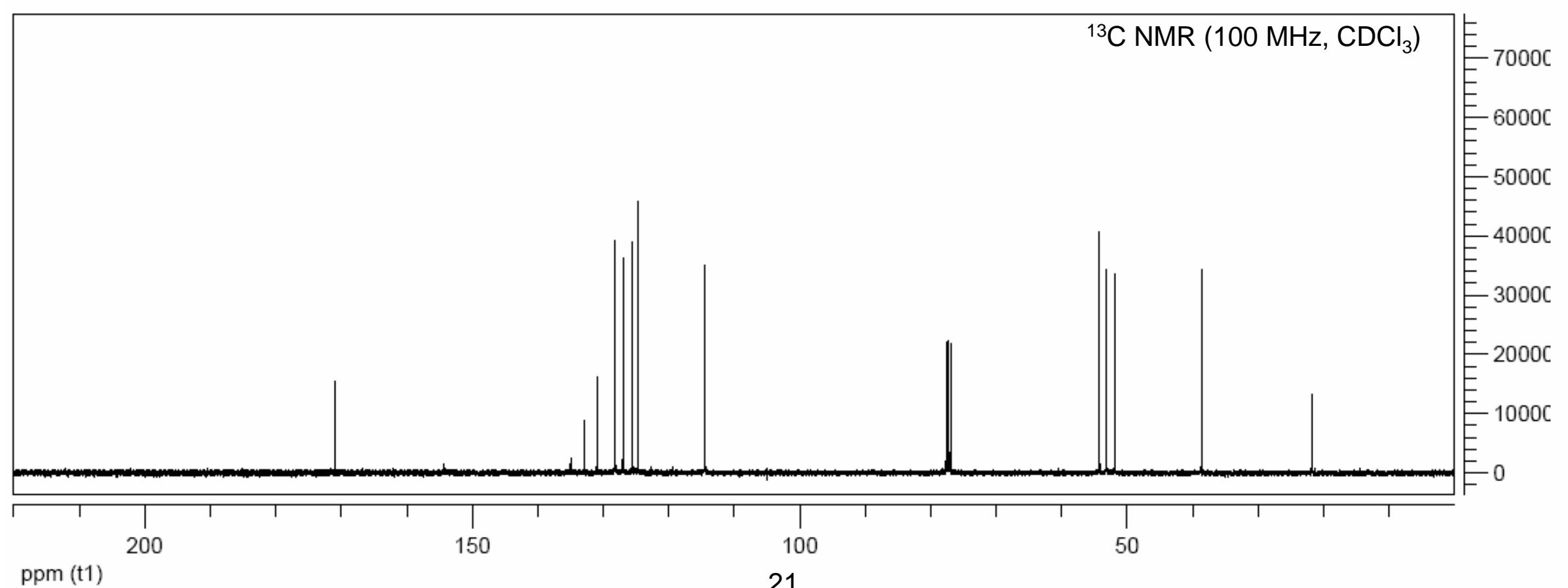




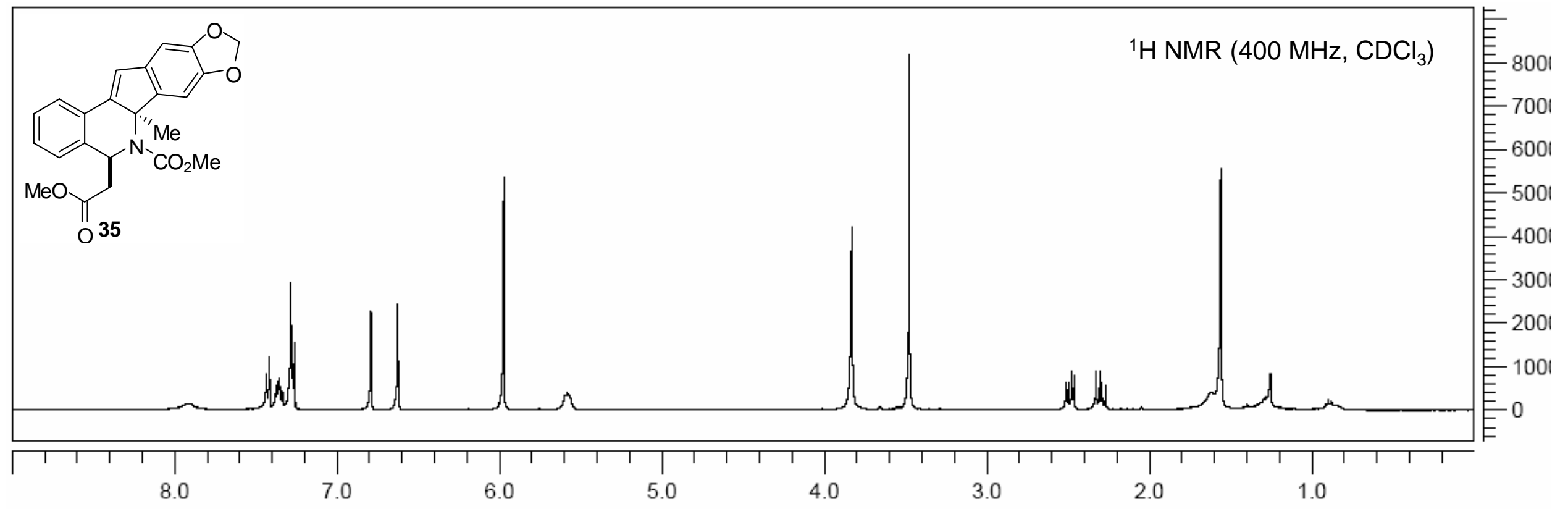

ppm (t1)

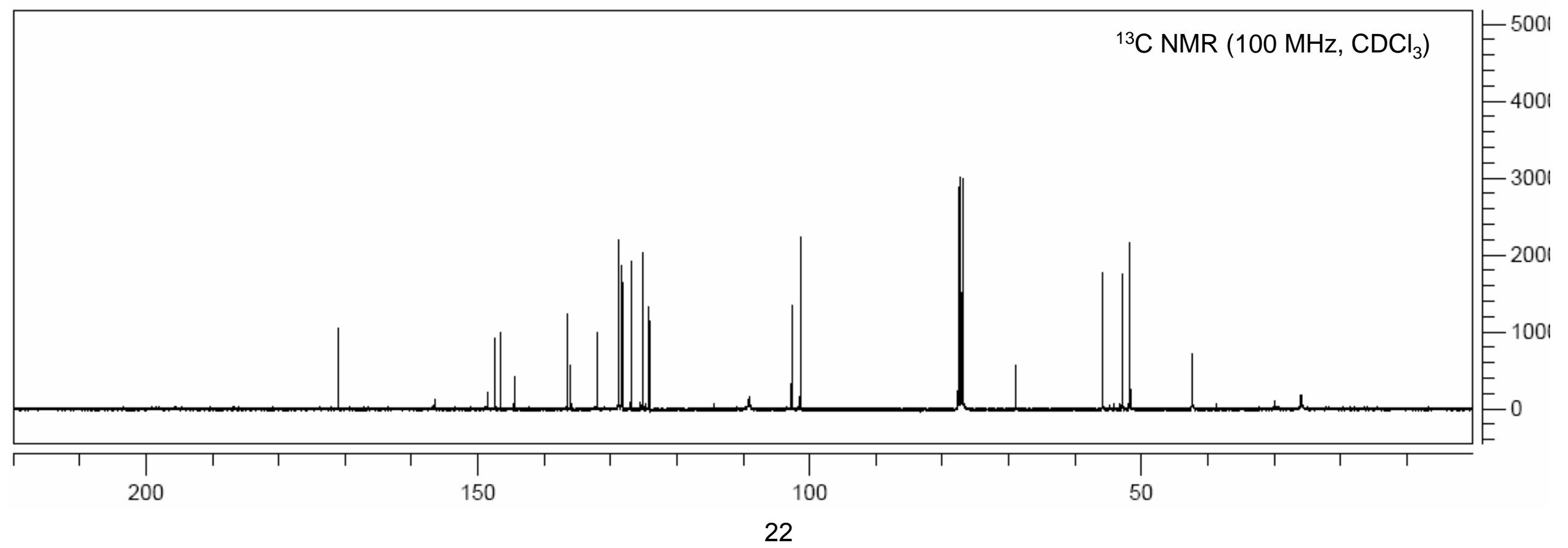




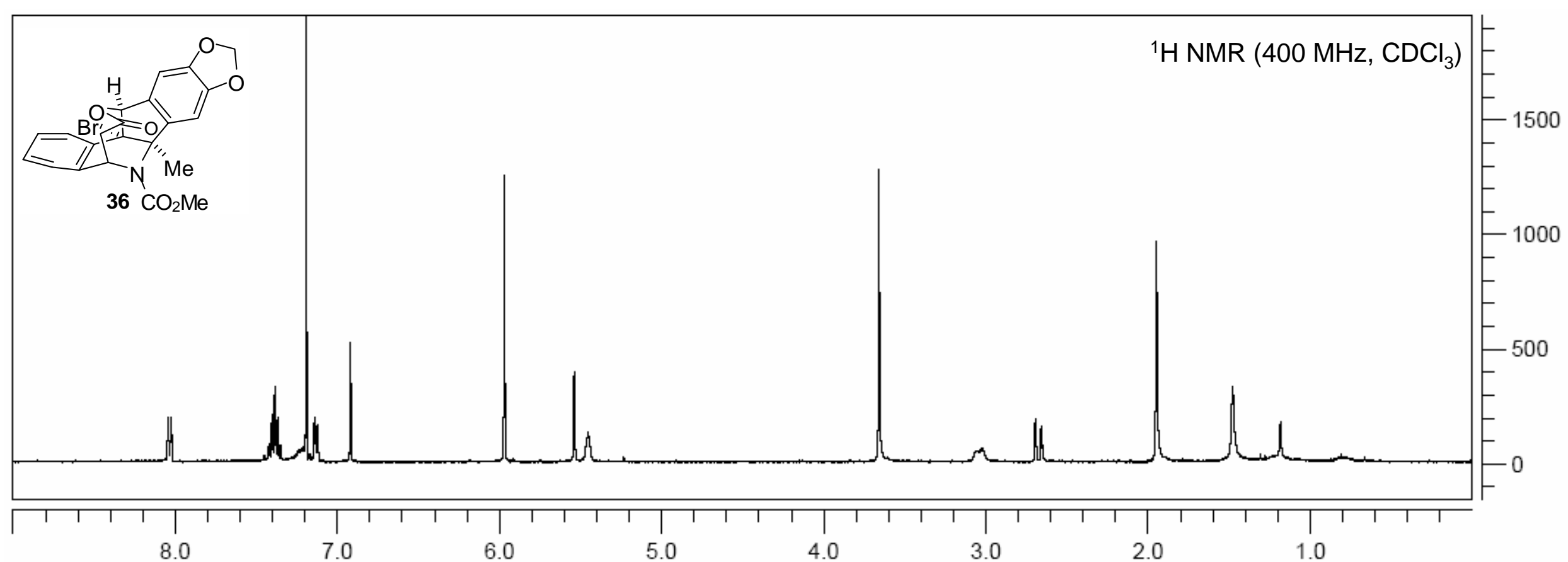

ppm (t1)

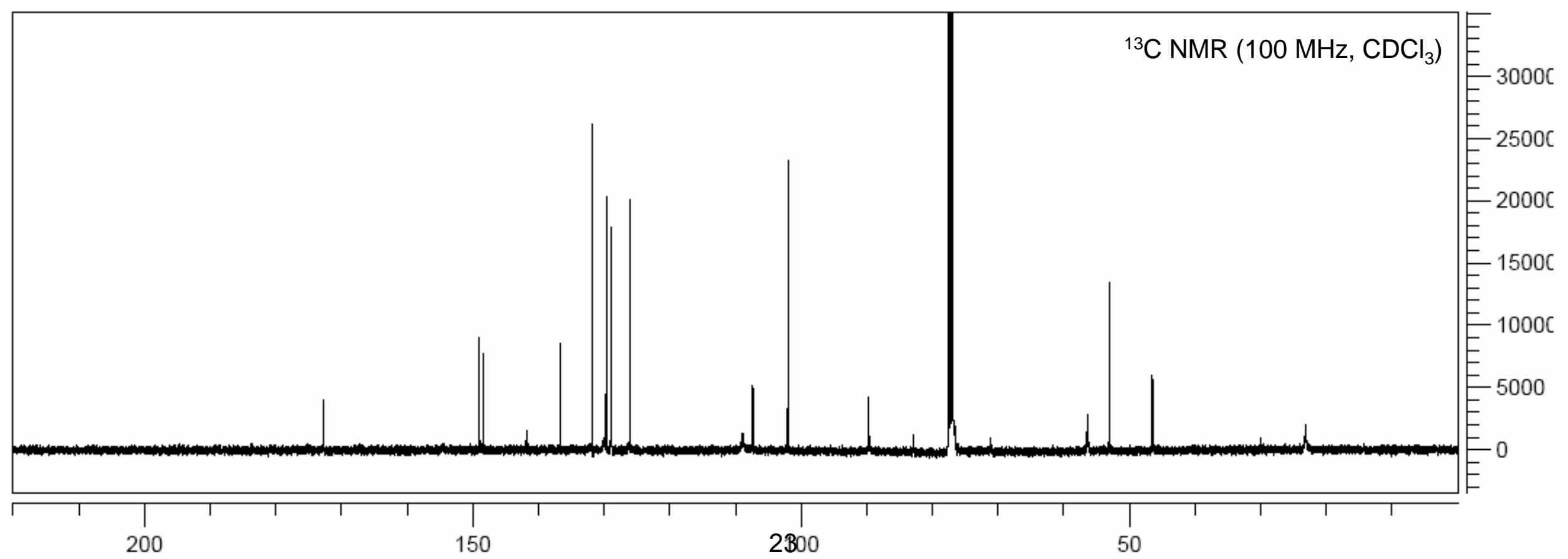




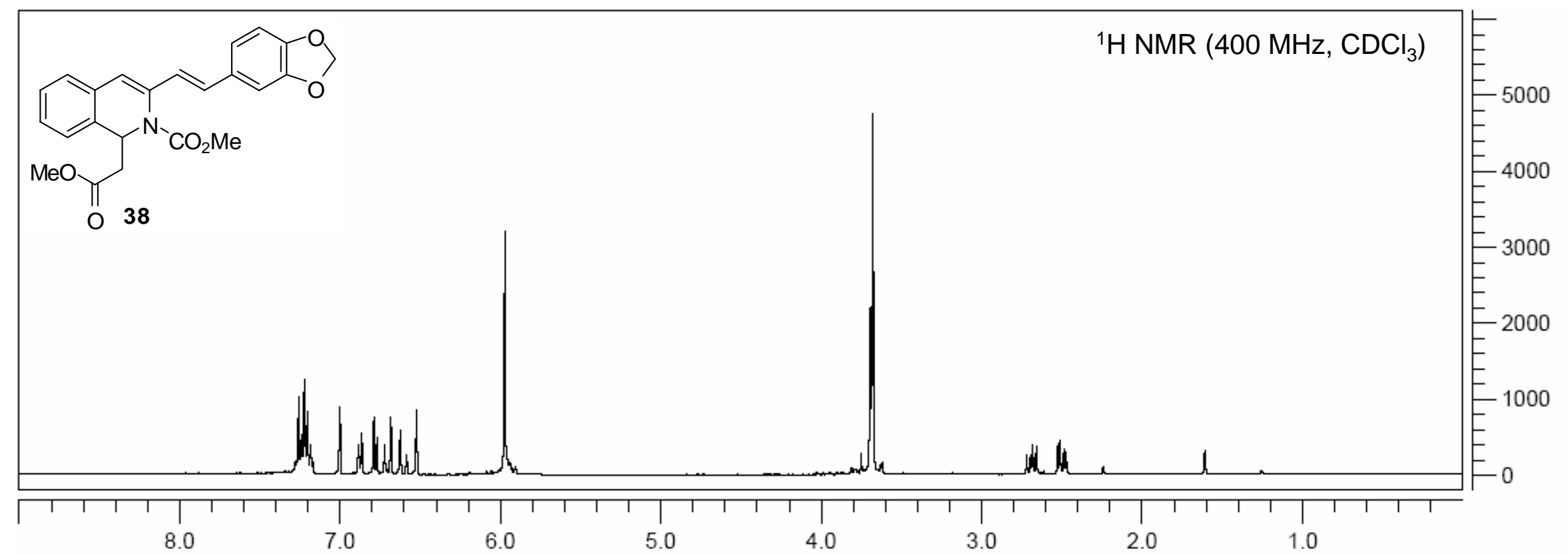

ppm (t1)

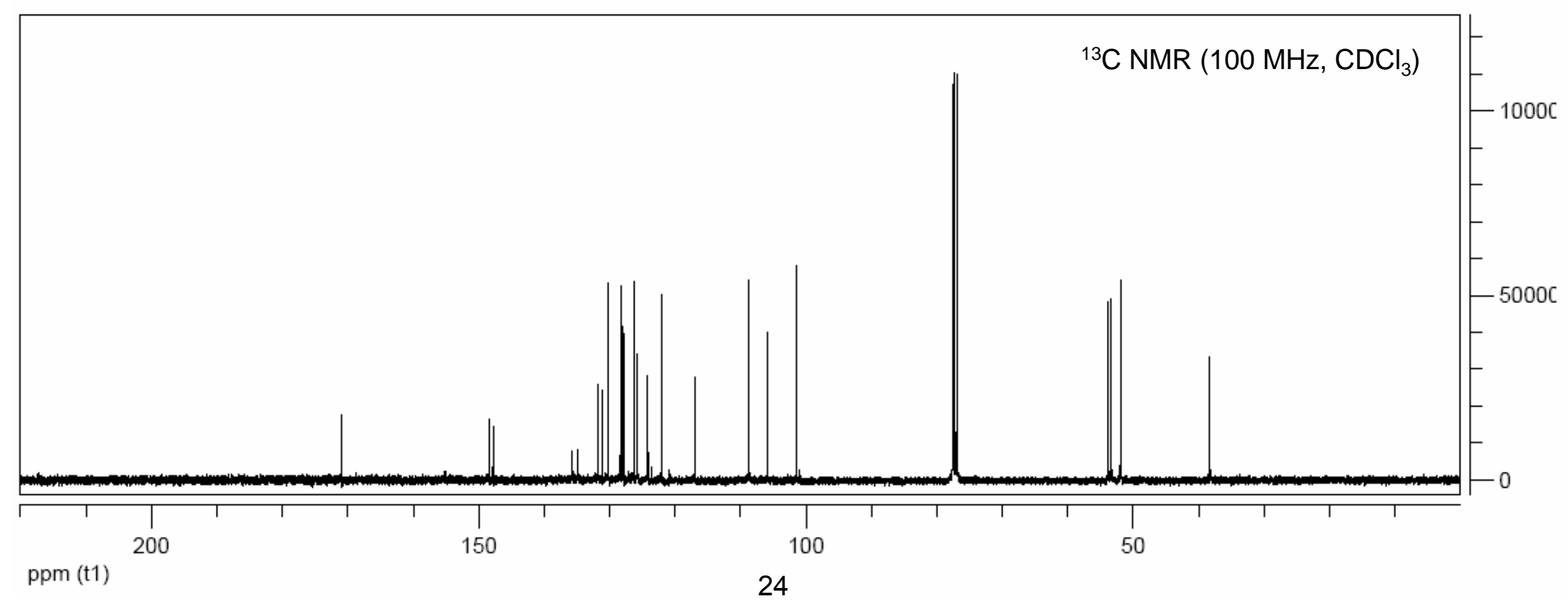




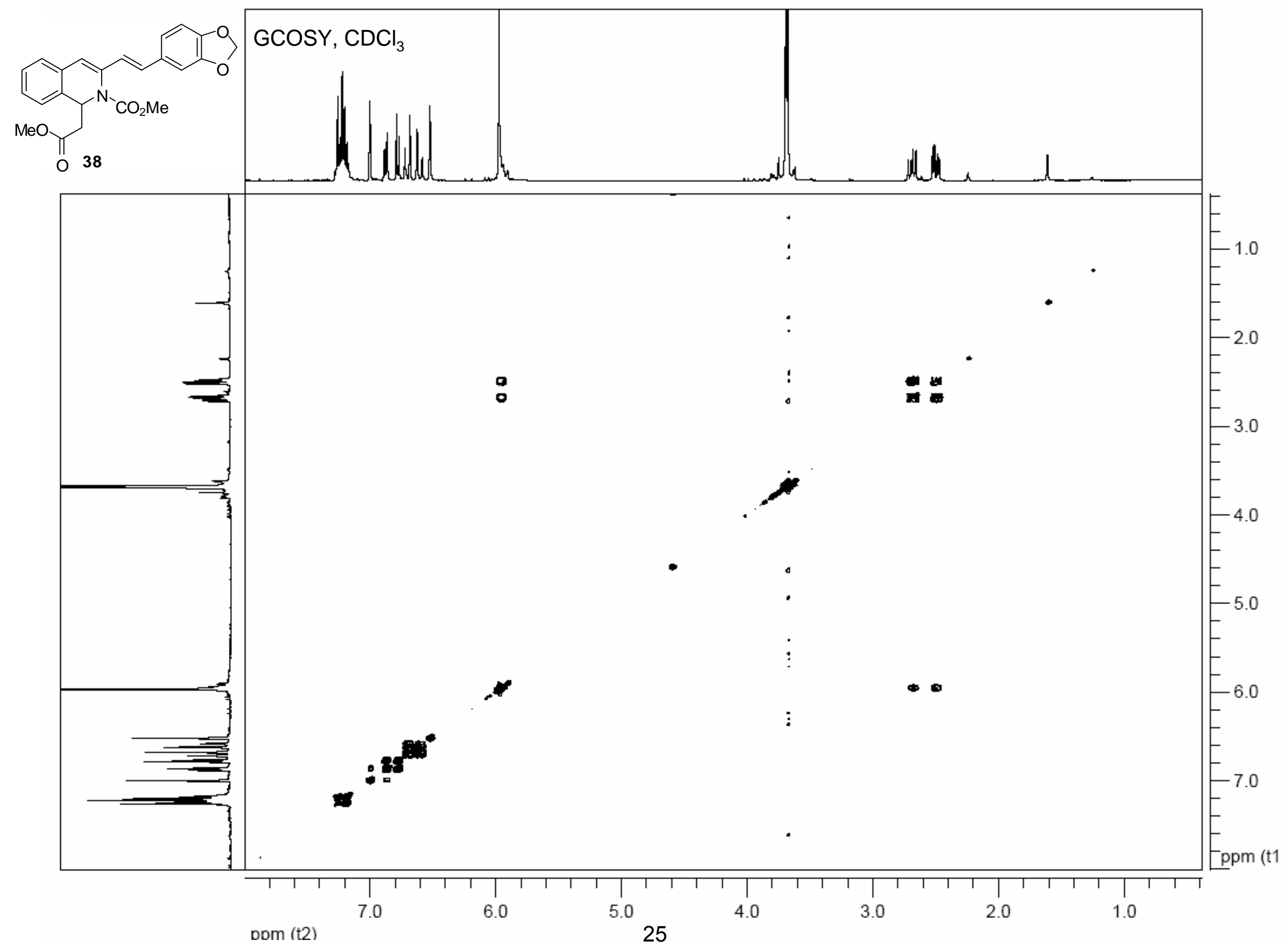




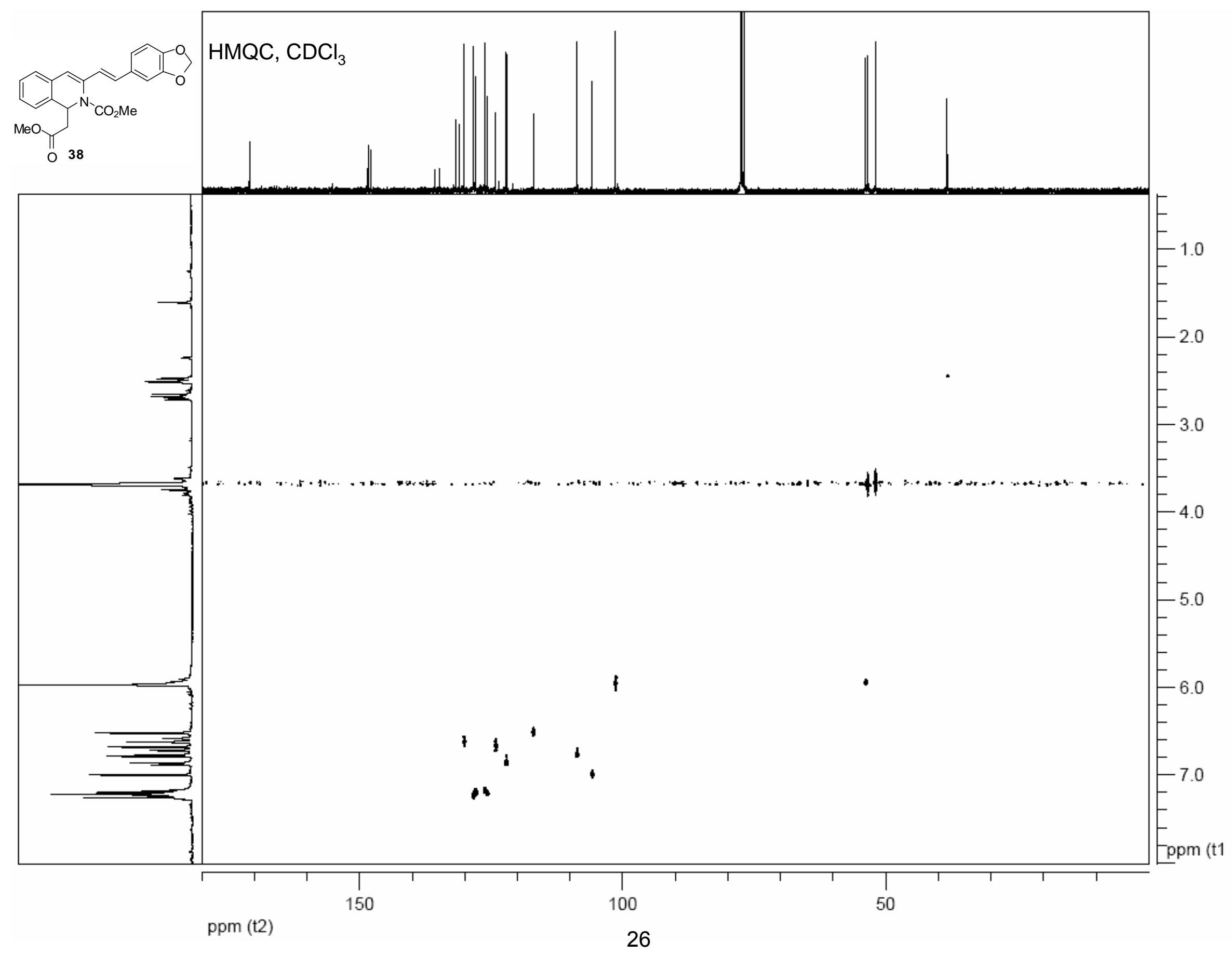




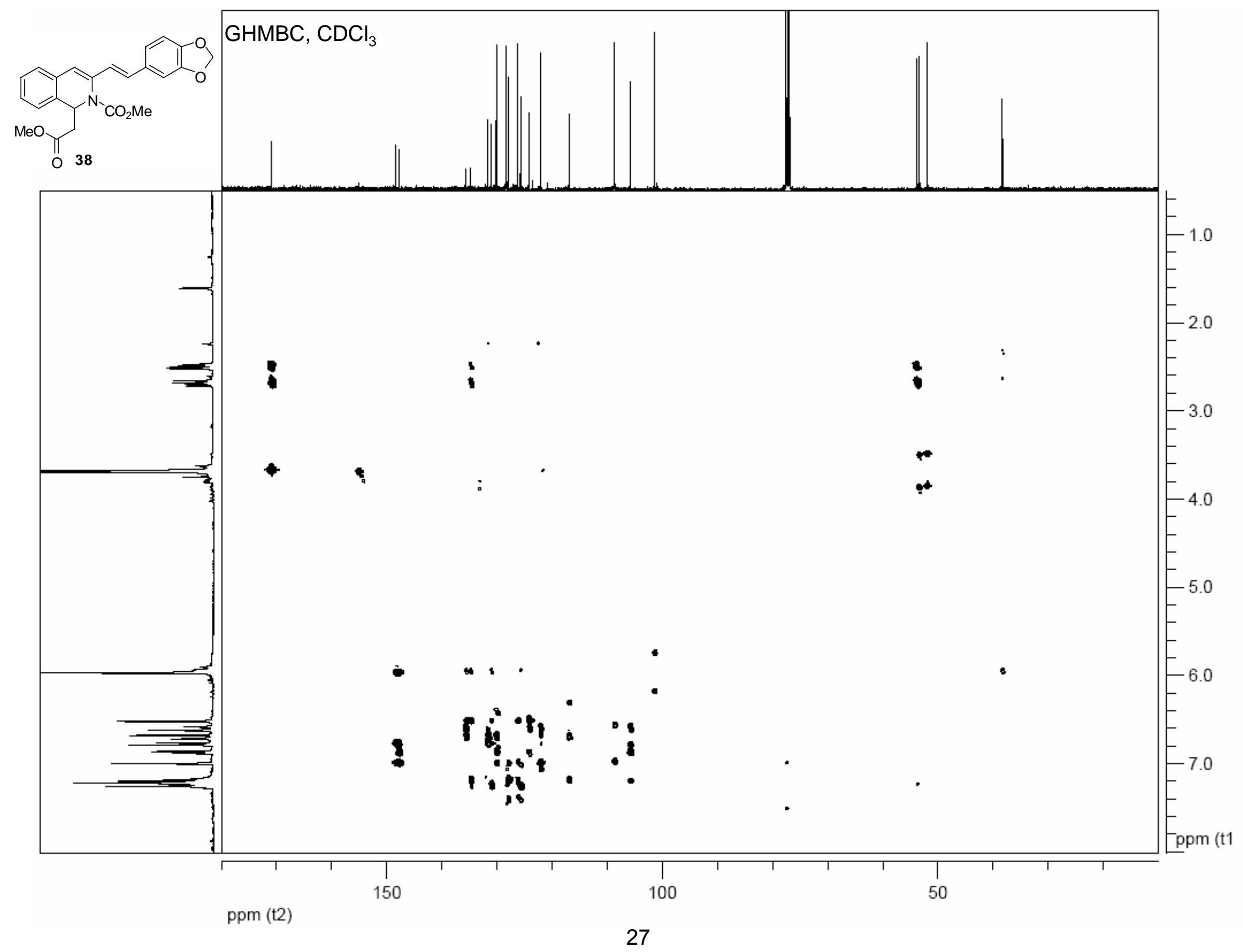



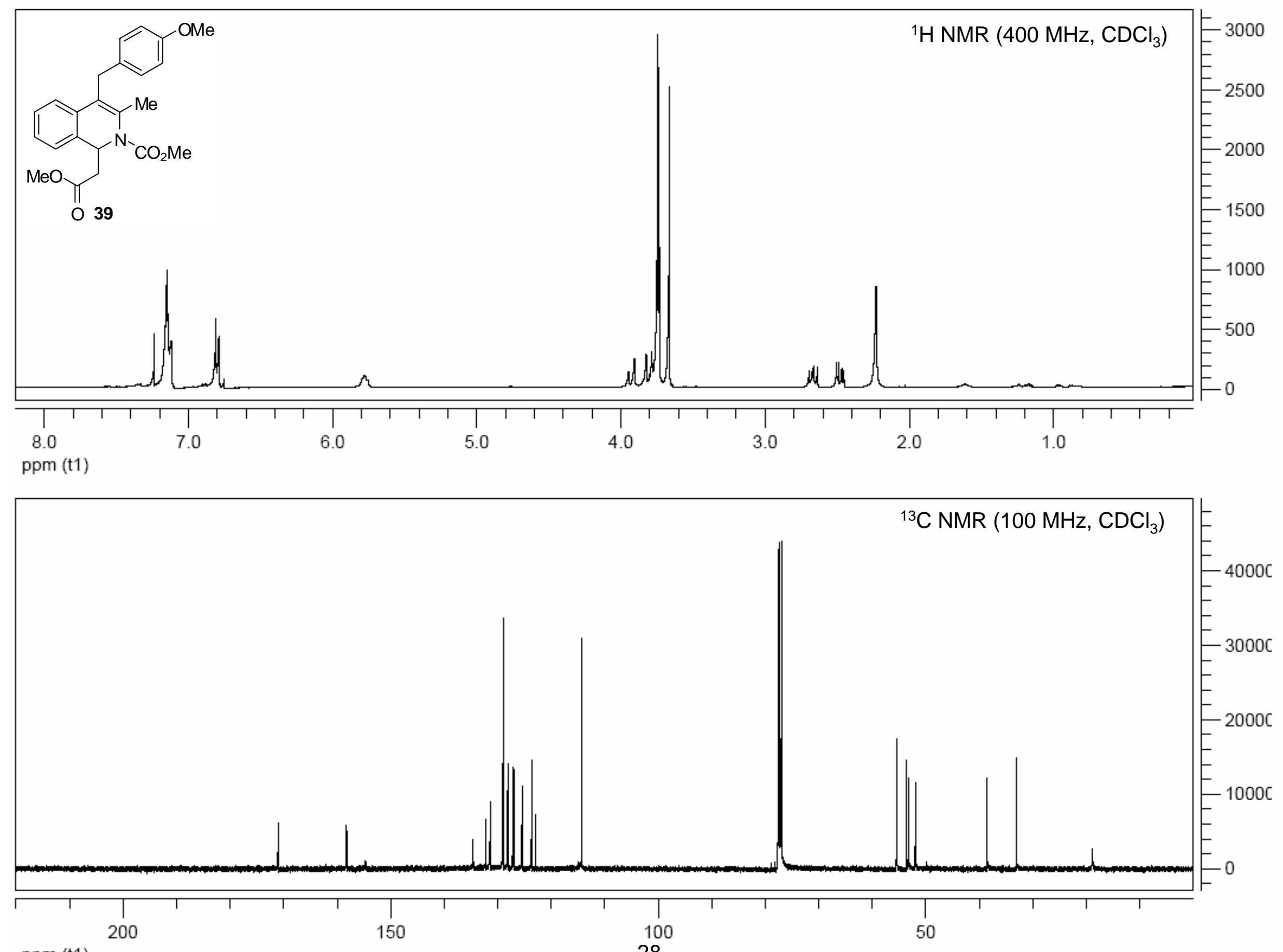

ppm (t1)

28 


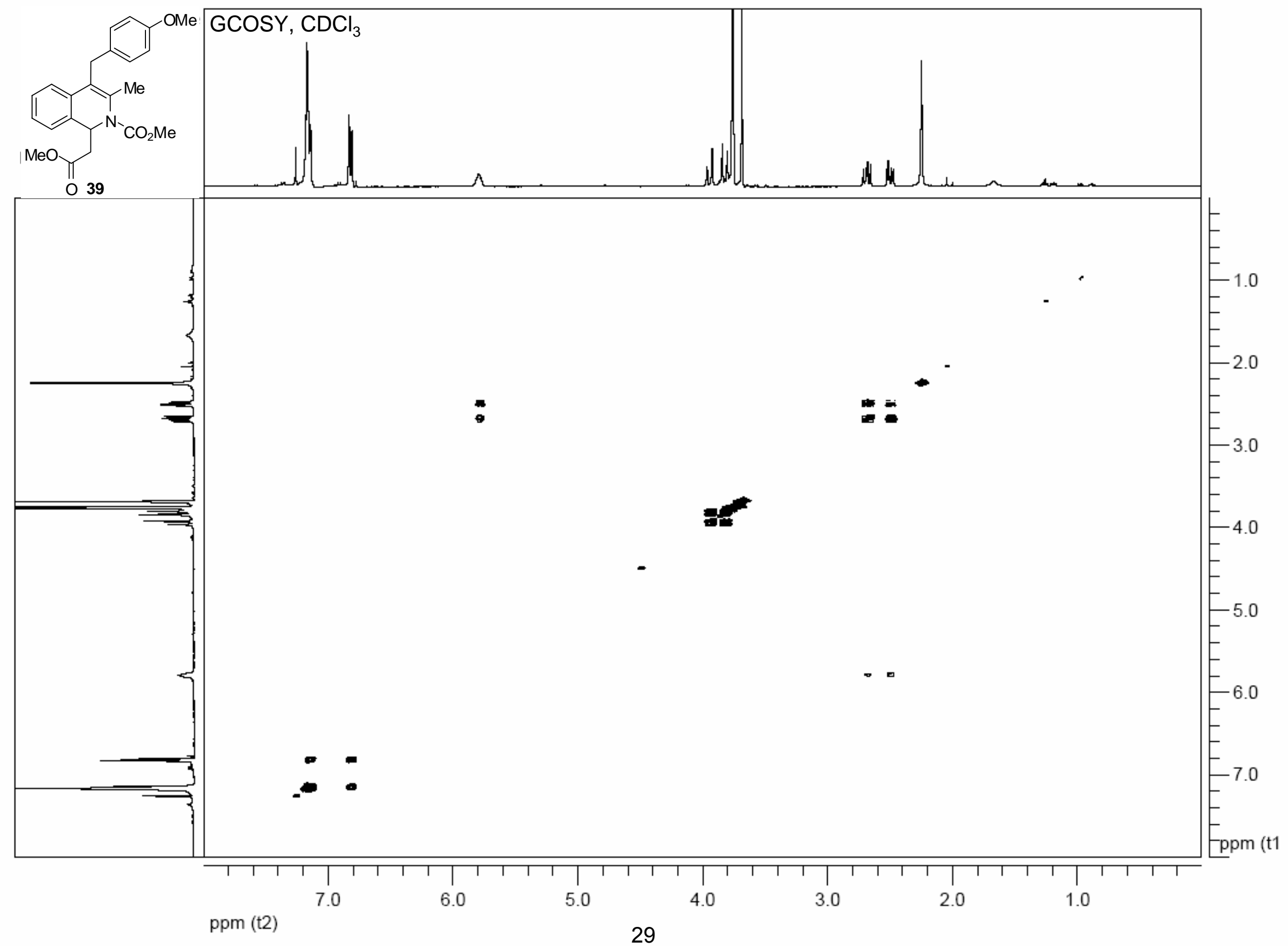




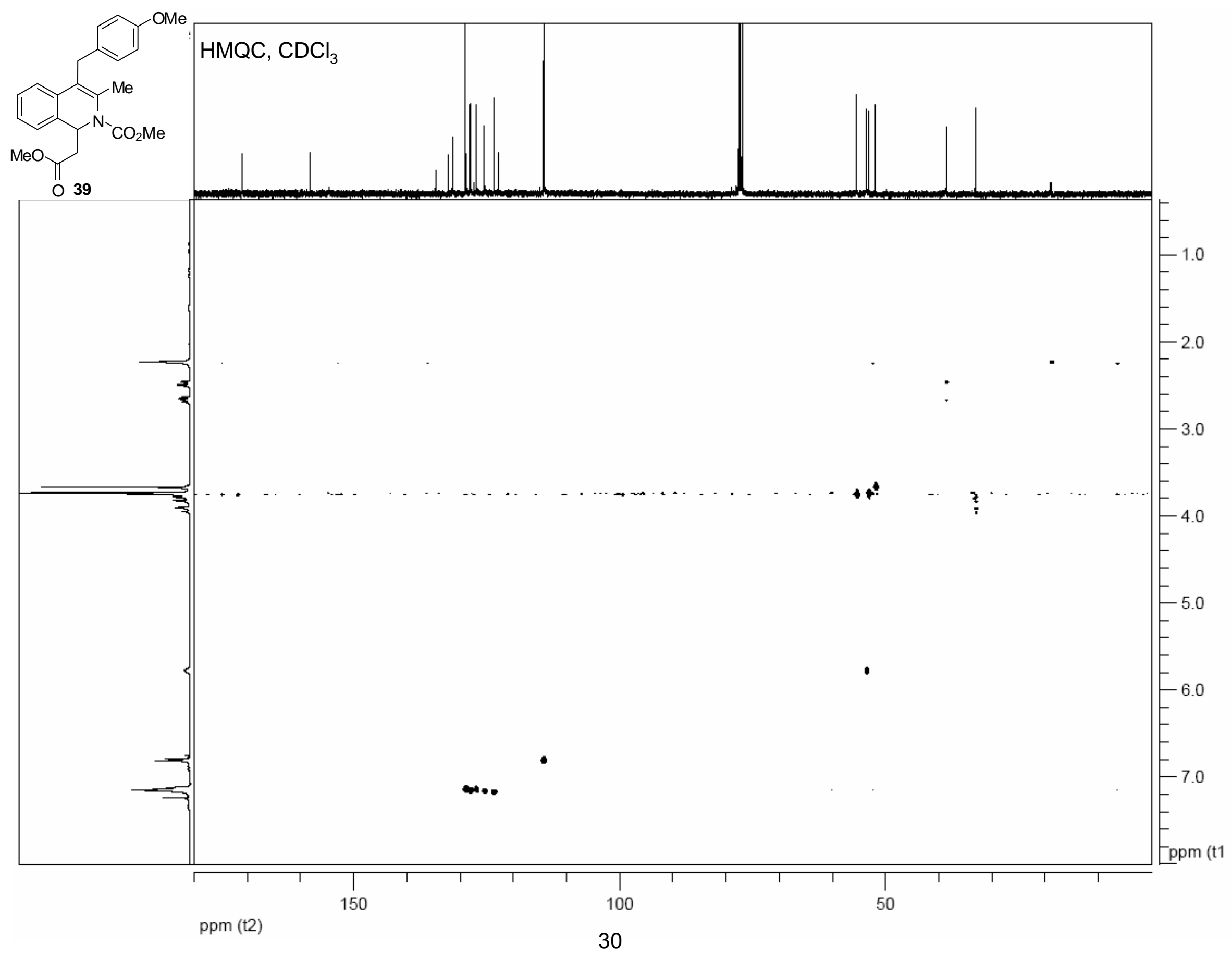




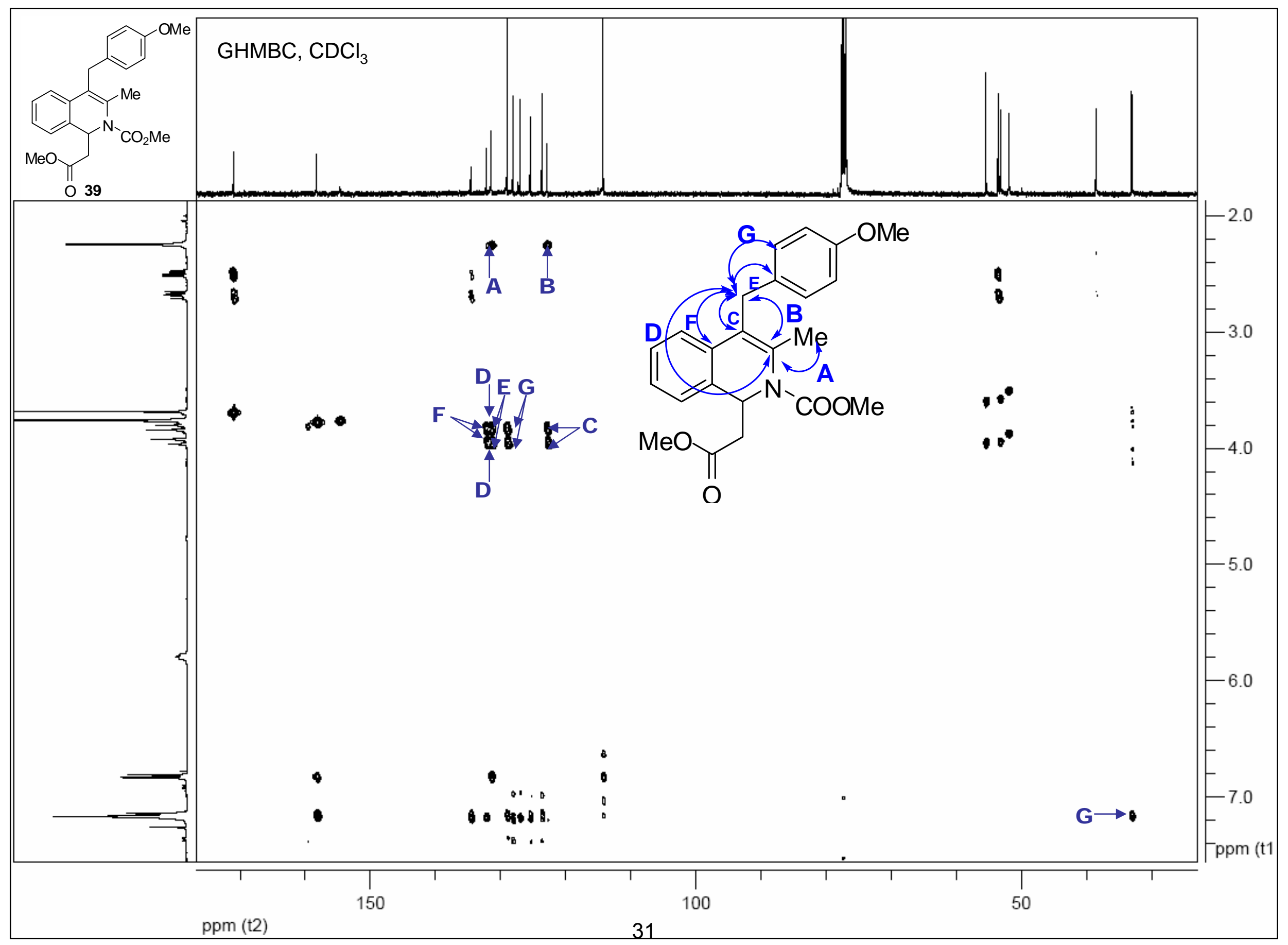




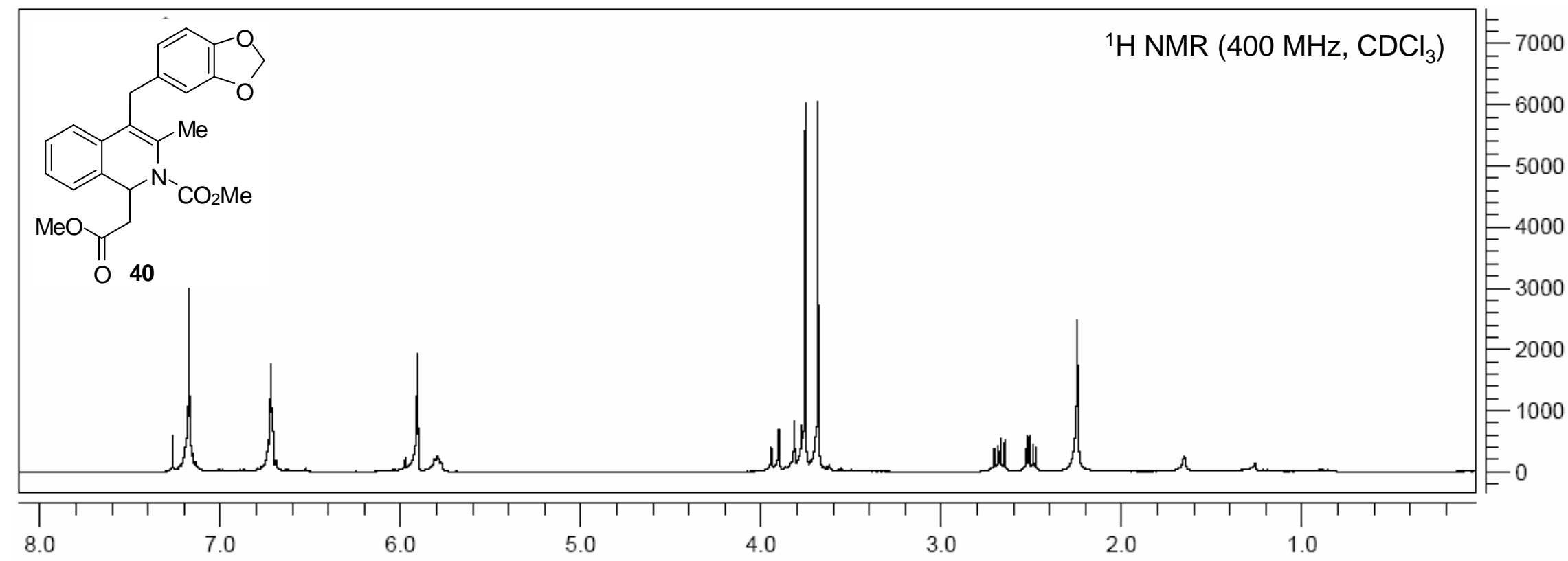

ppm (t1)

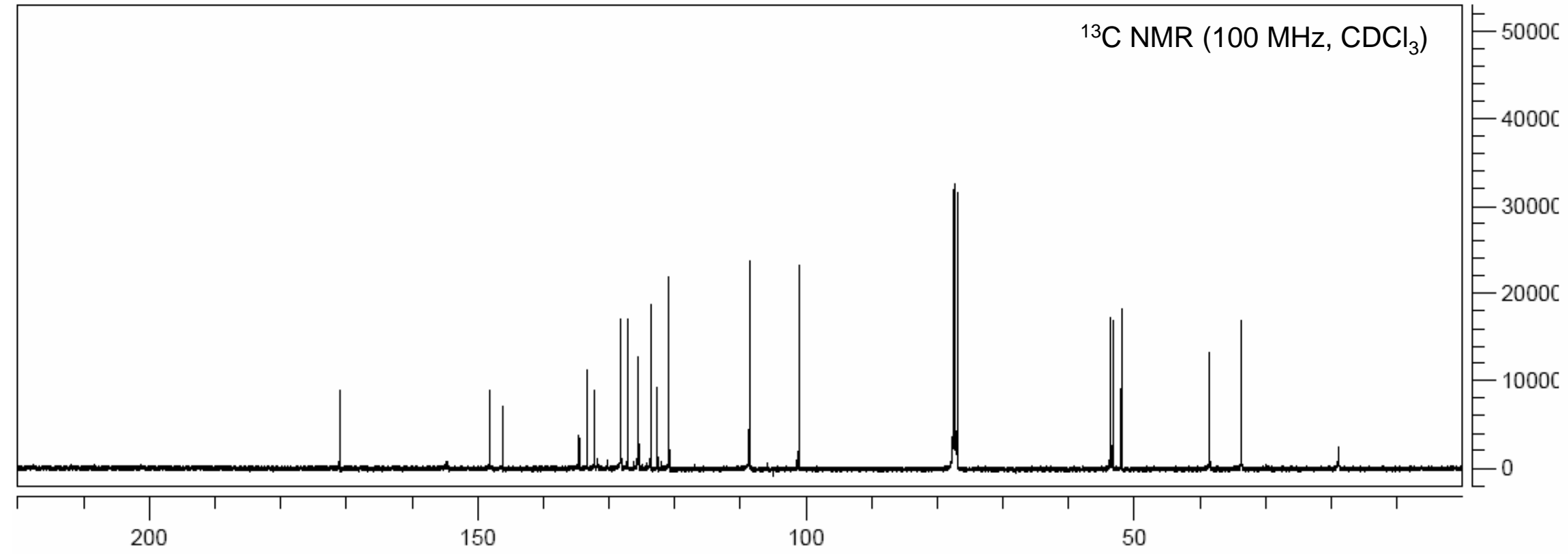

ppm (t1) 


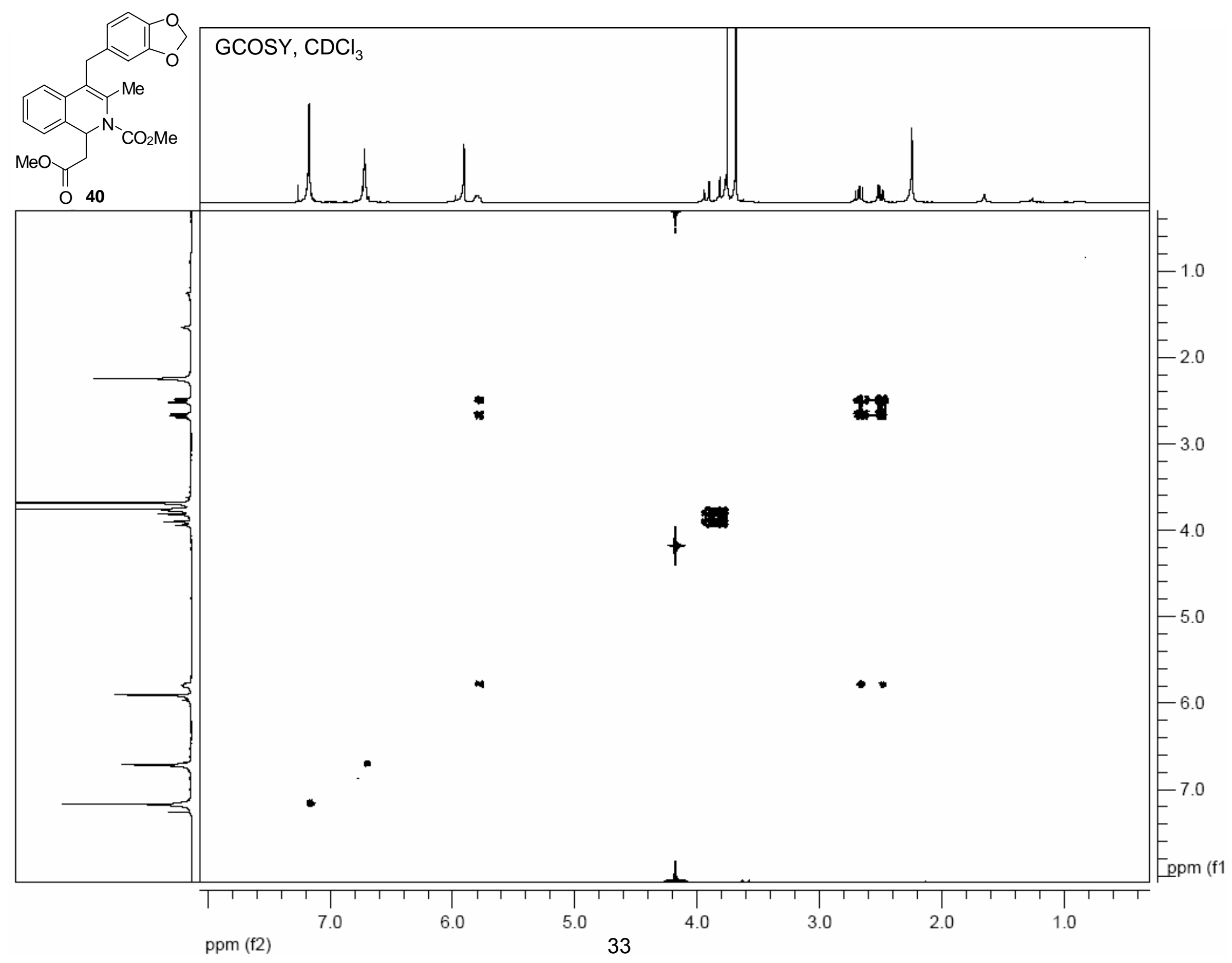




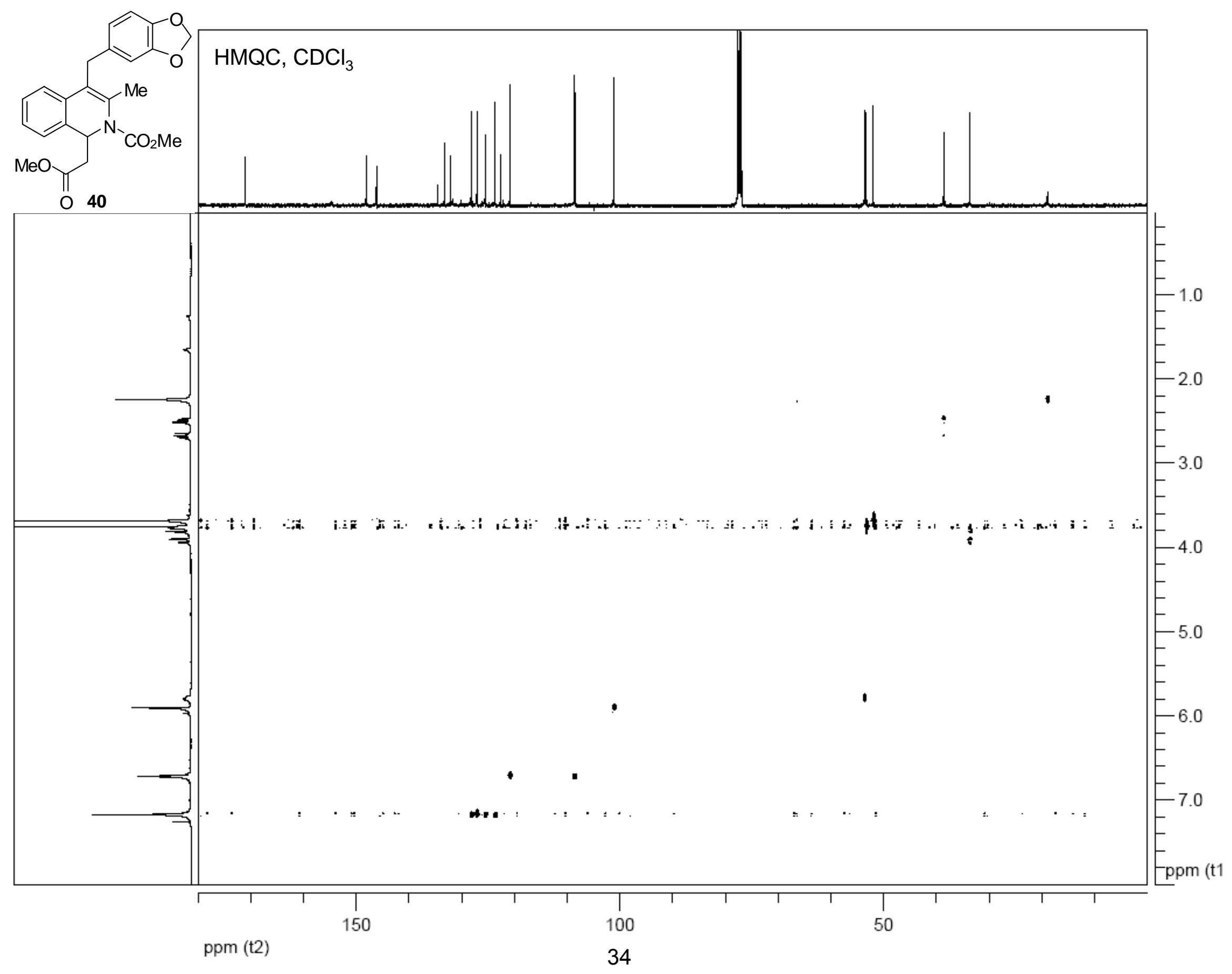




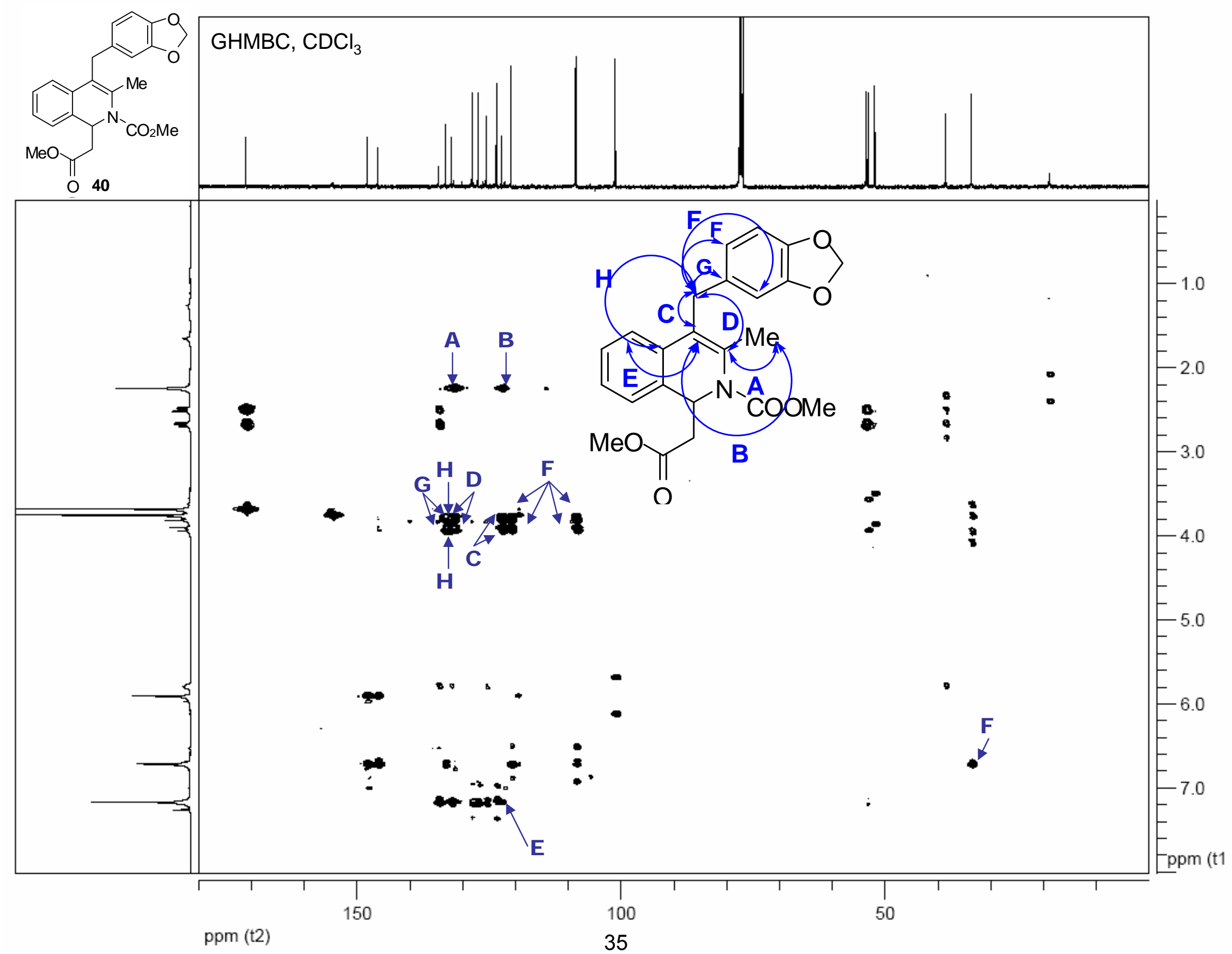




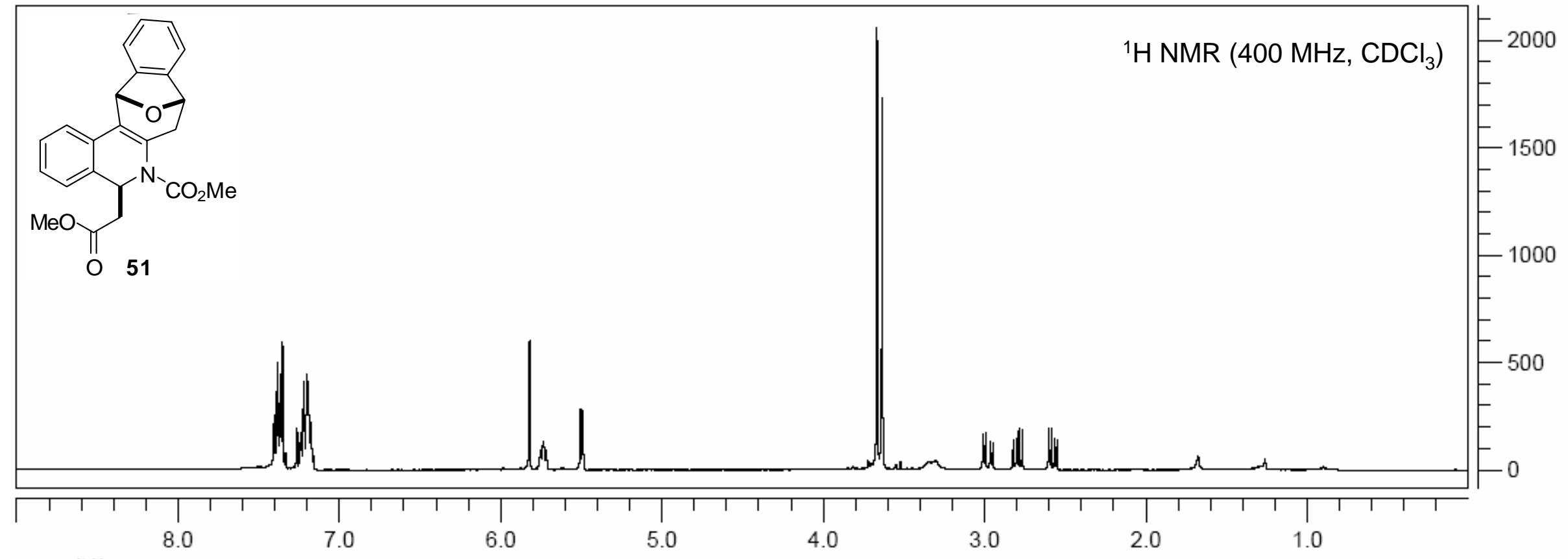

ppm (t1)

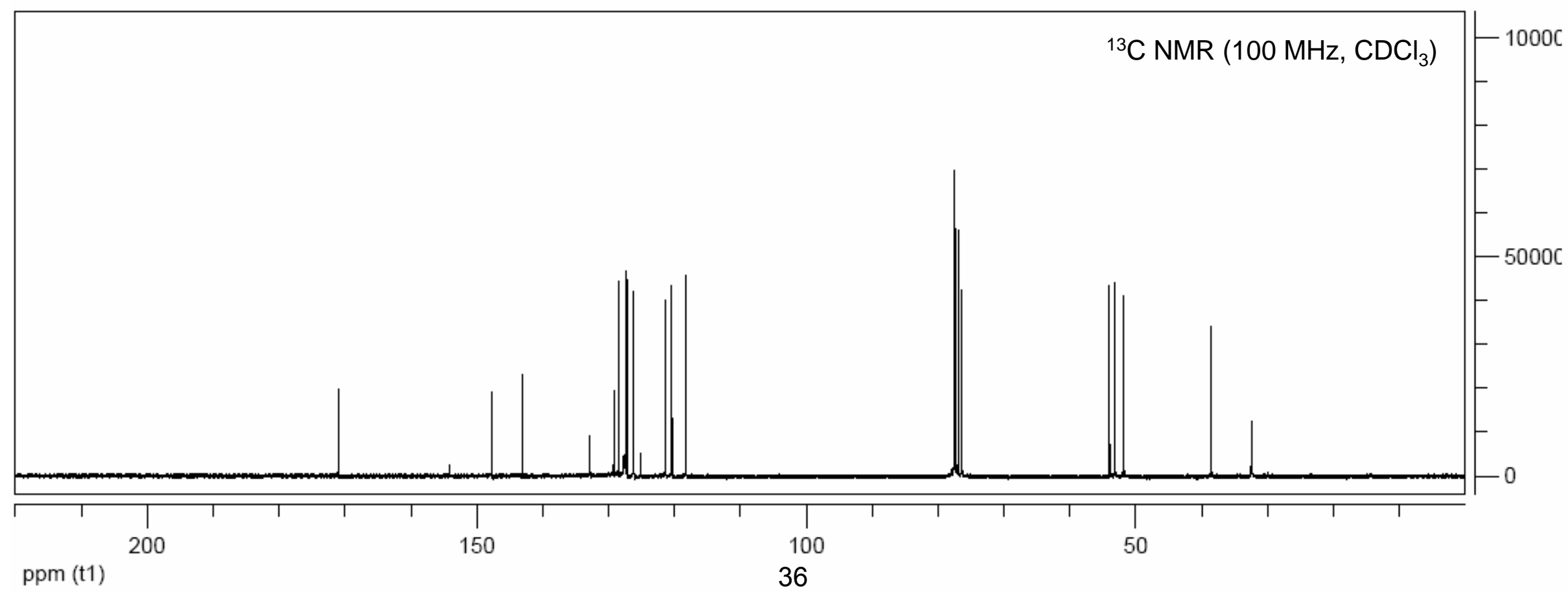




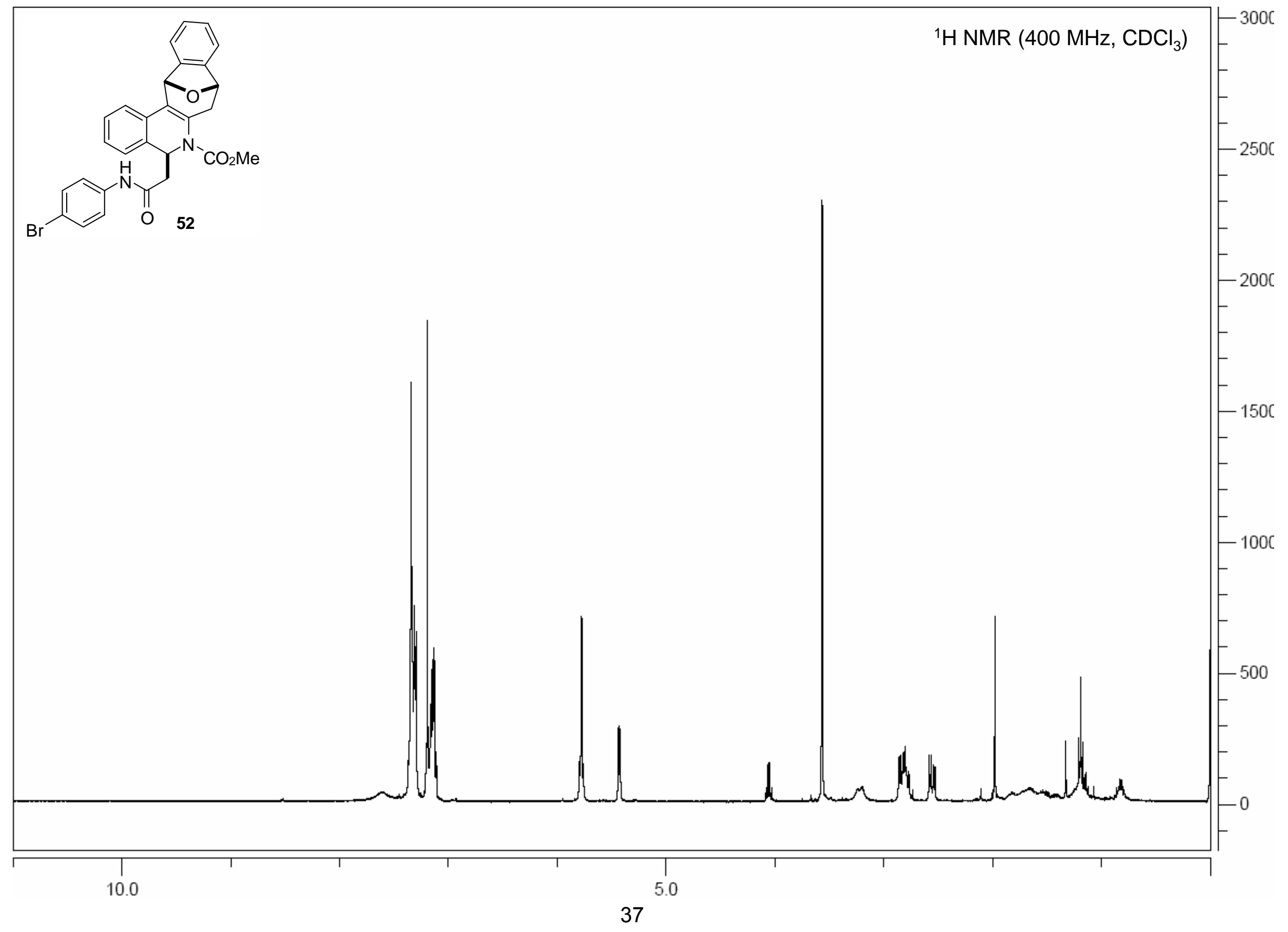

